\title{
The North Maladeta fault (Spanish Central Pyrenees) as the Vielha 1923 earthquake seismic source: recent activity revealed by geomorphological and geophysical research
}

\author{
Ortuño*1, M., Queralt ${ }^{1}$, P., Martí1 A., Ledo ${ }^{1}$, J., Masana*1, E., Perea ${ }^{2}$, H., Santanach*1, P. \\ ${ }^{1}$ Departament de Geodinàmica i Geofísica, Facultat de Geologia, Universitat de Barcelona \\ 08028 Barcelona (Spain) *Risknat Group \\ ${ }^{2}$ LATTEX, IDL, Fac. Ciências, Universidade de Lisboa, Lisboa (Portugal) \\ Corresponding author: maria.ortuno@ub.edu Tel.: +34-93-4034029 Fax: +34-934021340
}

\begin{abstract}
The Spanish Central Pyrenees have been the scenario of at least two damaging earthquakes in the last 800 years. Analysis of macroseismic data of the most recent one, the Vielha earthquake (19 November 1923), has led to the identification of the North Maladeta Fault (NMF) as the seismic source of the event. This E-W trending fault defines the northern boundary of the Maladeta Batholith and corresponds to a segment of the Alpine Gavarnie thrust fault. Our study shows that the NMF offsets a reference Neogene peneplain. The maximum observed vertical displacement is $\sim 730 \mathrm{~m}$, with the northern downthrown sector slightly tilting towards the South. This offset provides evidence of normal faulting and together with the presence of tectonic faceted spurs allowed us to geomorphically identify a fault trace of $17.5 \mathrm{~km}$. This length suggests that a maximum earthquake of $M_{w}=6.5 \pm 0.66$ could occur in the area. The geomorphological study was improved with a resistivity model obtained at Prüedo, where a unique detritic Late Miocene sequence crops out adjacent to the $N M F$. The section is made up of 13 audiomagnetotelluric soundings along a 1.5 $\mathrm{km}$ transect perpendicular to the fault trace at Prüedo and reveals the structure in depth, allowing us to interpret the Late Miocene deposits as tectonically trapped basin deposits associated with normal faulting of the NMF. The indirect age of these deposits has been constrained between 11.1-8.7 Ma, which represents a minimum age for the elevated Pyrenean peneplain in this part of the Pyrenees. Therefore, we propose the maximum vertical dip slip rate for the NMF to be between 0.06-0.08 mm/a. Normal faulting in this area is attributed to the vertical lithospheric stress associated with the thickened Pyrenean crust.
\end{abstract}

Keywords: Neotectonics, 1923 Vielha earthquake, Pyrenees, North Maladeta Fault, audiomagnetotellurics.

\section{Introduction}

The Pyrenean range (Fig. 1) is one of the most seismically active areas in Western Europe (Nicolas et al., 1990). Present day seismicity in the Central Pyrenees concentrates along the NW-SE trending Adour fault (Dubos et al. 2004) and in the surroundings of the Maladeta Massif (Souriau and Pauchet, 1998; Souriau et al., 2001). In this work, we focus on the Maladeta Massif area (Spanish Central Pyrenees), where two major seismic events occurred in the past: On the 3rd of February 1373, an earthquake with an estimated epicentral intensity $\left(\mathrm{I}_{0}\right)$ of VIII-IX (MSK) struck the Ribagorzana and Aran valleys and according to historical records, it was felt up to a distance of $350 \mathrm{~km}$ from the epicentral area (Olivera et al., 1994 and 2006). More than five centuries later, on the 19th of November 1923, the Vielha earthquake, with $\mathrm{I}_{0}=\mathrm{VIII}\left(\mathrm{MSK}\right.$ ) and $\mathrm{M}_{\mathrm{L}}=5.6$ (Susagna et al., 1994) occurred, producing local damage to buildings. This was the major seismic event to occur in Catalonia since the Middle ages.

This region is characterized by low to moderate seismic activity, and according to the Spanish Geographical Institute (Instituto Geográfico Nacional, IGN), at least 35 historic events with $\mathrm{I}_{0} \geq \mathrm{V}$ have been reported (Fig. 2). According to Souriau et al. (2001), the areal distribution of the 1986-1999 seismicity of this region suggests an alignment of the events associated with the Maladeta Massif. N-S cross-sections of the hypocentral depths for this period show a relatively scattered distribution of the earthquakes, suggesting that the events occur along 
fractures inside the Maladeta Massif and along a ductile-brittle boundary located at $12 \mathrm{~km}$ depth (Souriau and Pauchet, 1998). Olivera et al. (1996) recognise an alignment of the 1986-1989 microseismicity along fractures inside the massif. However, no tectonic structure, with or without a surface expression, has been identified as a seismogenic source so far.

The Global Seismic Hazard Assessment Map (Giardini et al., 1999) assigns a medium to low hazard value to the study area. At present, the Spanish building code (NCSE-2002) considers the area as a low seismic zone, with a maximum peak ground acceleration below 0.04 g. In this area of increasing urbanization, underestimation of the seismic hazard could give rise to erroneous decisions concerning the construction of buildings, hydroelectric dams and tunnels. A thorough review of the seismic risk of the region is of paramount importance and should include the recognition and characterization of the seismogenic sources.

The aim of this study is to determine the sources of the 1373 and 1923 damaging earthquakes and to elucidate their tectonic setting. To this end, we sought to:

1) Determine the location of the seismogenic sources by means of the macroseimic analysis of the events, following the methodology proposed by Gasperini et al. (1999) (henceforth the Gasperini method).

2) Identify the active structures responsible for the earthquakes and their tectonic regime based on surface information. Neotectonic features were primarily recognised by air-photo interpretation and analysis of topographic maps. The use of satellite images and a $30 \mathrm{~m}$ digital elevation model (DEM) for the area helped to visualize these features and to characterize the geomorphic markers displaced by the fault activity. This work was completed with a detailed field survey of the area.

3) Characterise the geometry of the active structures together with the linkage of scarps observed on the surface and vertical discontinuities recognisable at depth. This part of the research was based on subsurface information derived from an audiomagnetotelluric (AMT) survey.

\section{Geological setting}

\subsection{The Alpine orogen}

The Pyrenees are a doubly vergent collisional belt resulting from the MesozoicCenozoic interaction between the Iberian and European plates (Choukroune and ECORS, 1989; Choukroune 1992; Muñoz, 1992). The estimated shortening of the crust is $\sim 150 \mathrm{~km}$ (Muñoz, 1992) and the subduction of the Iberian lower crust is $80-100 \mathrm{~km}$ beneath the European crust (Muñoz, 1992; Pous et al., 1995; Souriau and Granet, 1995) (Fig. 1). Since the main Alpine compression, the Pyrenees have undergone a period of generalized relaxation of the compressive stresses with local tensional and compressional episodes. This period, which started during the Oligocene in the eastern part and after the Middle Miocene in the western part (Vergés et al., 1995; Capote et al., 2002), is referred to in this paper as the Neotectonic period.

The study area is located in the central part of the orogen, whose Alpine structure is characterized by a thrust system displaying an asymmetric double wedge of upper crustal rocks. Both the northern and the southern wedges consist of thrusted basement and cover rocks forming an imbricated system, thrusted northward and southward, respectively. Basement rocks in the southern wedge form an antiformal stack, classically known as the Axial Zone, composed of three main thrust sheets which, from top to bottom, are the Nogueres, Orri and Rialp units (see section A-A' in Fig. 1). The antiformal structure is the result of the Alpine convergence, which gave rise to the superposition, folding and steepening of the thrust sheets. Thrust faults separating the units are folded and dip to the South in the southern limb and to the North in the northern limb of the antiformal stack (Muñoz, 1992; Capote et al, 2002). The North Maladeta Fault (NMF), first described by Kleinsmiede (1960), is a segment of the north-dipping sector of one of these structures, the Gavarnie thrust. The fault can be seen in seismic profiles across the central Pyrenees (ECORS Pyrenees team, 1988) as a clear tectonic boundary strongly dipping to the North. It separates the granitic Maladeta Massif, a late Variscan intrusion located in the Orri thrust sheet, from the Devonian and Carboniferous sedimentary rocks intruded by granitic bodies in the Nogueres thrust sheet (Fig. 3).

\subsection{Quaternary landforms and deposits}


The highest peaks in the Pyrenees (Aneto, $3404 \mathrm{~m}$, Maladeta, $3308 \mathrm{~m}$ ) are located in the Maladeta Massif and form part of the the main watershed of the range. Glacial processes have conditioned the formation of the current landscape in the area, creating wide glacial cirques and "U" shaped valleys where moraines and glacial-lacustrine deposits have been preserved (Gutiérrez and Peña, 1981; Vilaplana, 1983; Bordonau, 1992; Calvet, 2004). At present, the steep slopes and bottoms of these valleys are partially covered with rock talus. Within this abrupt relief, glacial processes and high energy conditions have been unfavourable to the preservation of organized deposits that postdate the maximum Alpine orogenic convergence. The number of stratified and well preserved Neogene deposits in the area is very limited and consists, almost exclusively, of Miocene detritic deposits at the Aran Valley (Jelgersma, 1957; De Sitter and Zwart, 1962; Zwart, 1979) and glaciolacustrine and fluvial complexes at the Ribagorzana Valley (Vilaplana, 1983; Vilaplana et al. 1986; Bordonau, 1992). These latter deposits date or postdate the last glacial maximum, which based on ${ }^{14} \mathrm{C}$ and ${ }^{10} \mathrm{Be}$ datings, probably occurred after 25 ka BP (Pallàs et al., 2006).

\subsection{Instrumental data and field indicators of active tectonics}

Data concerning the Present-day stress regime in the Central Pyrenees are scarce and derived from borehole breakouts and earthquake focal mechanism solutions. The limited number of breakout data available for the Central Pyrenees (Jurado and Müller, 1997) show a WNW-ESE orientation of maximum horizontal stress $\left(\sigma_{\mathrm{H} \max }\right)$, which is in agreement with results obtained for the Present-day Western Pyrenean stress field (Rebaï et al., 1992).

In the Maladeta Massif area, only two earthquake focal mechanisms have been derived and show both normal faulting along both N-S and E-W planes and reverse faulting along NW-SE planes (Nicolas et al., 1990; Souriau et al., 2001, IGN, 2006). Goula et al. (1999) provide a focal solution for an earthquake in the nearby southeastern area showing right lateral strike-slip along an E-W plane (Fig. 2). Currently available data do not allow us to characterize the present-day faulting mechanism along the NMF. Although the 1923 Vielha $\left(\mathrm{M}_{\mathrm{w}}=5.3\right)$ earthquake took place during the instrumental period, it has not been possible to derive the associated focal mechanism to date.

Field indicators of Late Miocene-Quaternary tectonic activity in the study area are limited to the work carried out by Bordonau and Vilaplana (1986) and Moya and Vilaplana (1992). The scarps studied in these works are all located on the glaciated slopes of the Maladeta Massif and indicate normal faulting, some of them being parallel and adjacent to the E-W oriented NMF trace considered here. However, the size and topographic emplacement of these scarps suggest that surface gravitational processes act as important controlling factors of the deformation, making it difficult to distinguish the tectonic component of the faulting. On the northeastern border of the Massif, Ortuño et al. (2004) described the geomorphological expression of the E-W trending NMF, characterized in detail in the following sections.

Additional evidence of recent faulting in the Central Pyrenees has been found in a more southern position, $\sim 30 \mathrm{~km}$ North of Lleida (Fig. 2), reflecting N-S to NE-SW oriented and subhorizontal maximum stress $\left(\sigma_{1}\right.$; Goula et al., 1999). These sites are located in areas where salt tectonics is taking place; hence, one must proceed with caution when interpreting these data in terms of tectonic stresses.

Owing to the scarcity, poor quality and lack of uniformity of the results, currently available field and seismotectonic data for the Central Pyrenees do not allow us to define the neotectonic stress field for this region. As discussed in section 8, this situation is not unique to the Central Pyrenees but characterizes the whole range.

\section{Analysis of the 1923 and 1373 events}

In order to determine the seismogenic sources of the Vielha (19.11.1923) and the Ribagorza (2.3.1373) earthquakes, macroseismic data obtained from Susagna et al. (1994) and Olivera et al. (2006), respectively, were processed following the Gasperini method. We used the program "Boxer 3.1" (Gasperini, 2001) for the calculation of the seismic source parameters.

The Gasperini method was designed to localize the seismic source of historical earthquakes in Italy and assumes a seismogenic dip-slip fault with a $45^{\circ}$ dip angle and a minimum size earthquake $\mathrm{M}>5.5$ (corresponding to a minimum rupture length of $7.5 \mathrm{~km}$ ). It 
consists in a statistical analysis of the geographical distribution of earthquake intensity points and provides the surface projection of the most probable rupture area. In this regard, the assumption of a $45^{\circ}$ dip is reflected as a range of confidence that would be smaller if the fault is steeper. If the amount of data is insufficient, the solution corresponds to a circle, whose centre coincides with the earthquake epicentre. The diameter of the circle corresponds to the fault length. No information on the fault azimuth is achieved in this case. If a sufficient number of intensity points are analyzed, the output data consist of four coordinate points, which define the rupture area surface projection as a rectangle centred on the earthquake epicentre. Thus, the rectangle contains information on the physical dimensions, orientation and location of the most probable seismic source, whose surface intersection should coincide with one of the two longest sides of the rectangle. The length and width of the rupture zone are obtained from Wells and Coppersmith (1994) relationships.

Further comparison with the geology of the area enables us to identify faults located near or within this surface projection with the result that, possible sources of the earthquake could be considered.

\subsection{The 1923 Vielha earthquake}

The macroseimicity and the instrumental seismic record of the Vielha earthquake (19.11.23) were analyzed by Susagna et al. (1994), who determined a local magnitude of 5.6 and a focal depth of $5 \mathrm{~km}$ for the event. The macroseismic field compiled by these authors is considered here (Fig. 5) as the input data for the identification of the seismogenic source. These data consist of a total of 465 points from the Spanish and the French territories with intensities ranging between II and VIII (MSK). Application of the program "Boxer 3.1" to these points yields an epicentre located at $42^{\circ} 42^{\prime} \mathrm{N}, 0^{\circ} 47^{\prime} \mathrm{E}$, almost coincident with that estimated by Susagna et al. (1994; 42 $\left.40^{\circ} \mathrm{N}, 0^{\circ} 42^{\prime} \mathrm{E}\right)$. The output seismogenic source projection corresponds to the rectangle represented in figure 6. The source has an approximate E-W strike and has rupture dimensions that correspond to a $\mathrm{M}_{\mathrm{w}}=5.8$ earthquake, which is slightly greater than the $\mathrm{M}_{\mathrm{w}}=5.3$ earthquake inferred from the seismic moment $\left(\mathrm{M}_{\mathrm{o}}=1.1 \times 10^{17} \mathrm{~N} \times \mathrm{m}\right)$ provided by Susagna et al. (1994). This $\mathrm{M}_{\mathrm{o}}$ value is derived by the authors from the analysis of the instrumental record and should be more accurate than the estimation performed through the Gasperini method, which is exclusively based on macroseismic data.

The surface projection of the seismogenic fault zone obtained through this analysis matches the westernmost part of the NMF morphologic expression. Since the NMF is the only fault showing recent activity in the proximity, this solution suggests that the NMF is the most probable source of the Vielha earthquake. The location of the near field intensity points (Fig. 5) is strongly controlled by the irregular distribution of the villages in this zone, where towns are aligned along narrow valleys separated by large unpopulated areas. A slight departure in the rectangle orientation in relation to the NMF trace is expected owing to the absence of towns in the immediate vicinity to the southwest and the lack of data for the adjacent western area.

\subsection{The 1373 Ribagorza earthquake}

At the end of the XIV century, when the Ribagorza earthquake occurred, the epicentral zone (High Ribagorzana Valley) was sparsely populated. Given its location in a border region, important defensive fortifications and Romanesque churches had been built in the area. Hence, the reports of the damage affecting these structures were preserved in several historical archives. The work of compilation and evaluation of these data carried out by Olivera et al. $(1994 ; 2006)$ provides a set of 21 intensity points, with values ranging from intensity I=IV to an epicentral intensity $\mathrm{I}_{0}=$ VIII-IX (MSK), and an epicentre located at $42^{\circ} 38^{\prime} \mathrm{N}$ and $0^{\circ} 41^{\prime} \mathrm{E}$ with an uncertainty of 20-50 km (Fig. 2 and 6). Analysis of the areal extension of the isoseismals has led the authors to estimate a hypocentral depth between 10 and $20 \mathrm{~km}$ and an associated moment magnitude of $\mathrm{M}_{\mathrm{W}}=6.2$ for the earthquake. Owing to the scarcity and rough location of the intensity points and to the lack of data for the south-western sector, the Gasperini method does not provide a reliable source location. However, within the area of epicentre uncertainty, the NMF is the only structure to which recent tectonic activity has so far been assigned (Ortuño et al. 2004). For this reason, the NMF cannot be ruled out as the seismic source of the 1373 Ribagorza earthquake. 


\section{Surface indicators of active tectonics}

Once the NMF was identified as a seismogenic fault, a study of the geology and geomorphology of the area surrounding the Vielha earthquake epicentre was conducted in order to better characterise the fault and its activity.

Air-photo interpretation was based on 1:18000 scale photographs and was combined with the analysis of topographic maps at different scales (1:50000, 1:25000 and 1:5000) as well as with observation of ortho-rectified satellite images (1:25000 and 1:5000) obtained from the Institut Cartogràfic de Catalunya (ICC). Neotectonic features were evaluated by close inspection in the field. Especial attention was paid to the mapping of lithological contacts with associated rectilinear scarps and recent deposits in the areas adjacent to tectonic faults in order to clarify the neotectonic imprints (Fig. 4). As a result of the field survey, a neotectonic map of the area was made including Quaternary surface faulting and displaced geomorphic markers. The observations made were contrasted with some $3 \mathrm{D}$ topographic basic analyses performed using a $30 \mathrm{~m}$ DEM.

\subsection{Elevated Pyrenean peneplain}

On both sides of the Garona valley and to the north of the NMF, the irregular topography of the region becomes smoother and a regional peneplain is recognised as a prominent feature of the landscape. Peneplains in the study area were already mentioned by García Sáinz (1935; 1940) and Zandvliet (1960). Kleinsmiede (1960) describes them in detail and distinguishes three levels at different altitudes. The peneplain relicts have long been interpreted by Pyrenean geologists as the remains of a wide regional erosive surface developed on the top of the Pyrenean range prior to the Plio-Quaternary rejuvenation of the landscape by river incision. Calvet (1985) describes similar surfaces in the Eastern Pyrenees and recognises two different generations, one pre-dating Late Oligocene times and the other dated between the Middle and the Late Miocene. In our interpretation of the local landscape, as discussed below, we assume the existence of a single regional erosive surface predating the Quaternary glaciations, regardless of the present debate on its origin (Calvet, 1985; Babault et al., 2005; Calvet and Gunnell, 2005; Babault et al., 2006; Gunnell and Calvet, 2006).

North of the NMF, the peneplain has altitudes ranging between $2000-2230 \mathrm{~m}$ and is dissected by the hydrographic network into several relicts, suspended 400-500 m over the Garona river. Between the NMF and the Garona valley, the relicts reach areal dimensions of almost $7 \mathrm{~km}^{2}$ and are termed, from West to East, Mieidia, Malh de Vivers, Prüedo and Porèra (Fig. 4). The surfaces have only been slightly modified by the glacial tongues: Prüedo and Porèra peneplain relicts are locally capped with glacial till whereas Mieidia and Malh de Vivers relicts do not show any signs of having been glaciated.

In the southern wall of the fault, surface relicts are reduced to narrow and flat areas with average altitudes ranging from $2400-2500 \mathrm{~m}$. The correspondence of these areas with the old peneplain is better visualized by drawing a surface envelope linking all the summits, which all have similar heights in this area (Fig. 7 and 8). Both in the field and in 3D images obtained from a DEM, it can be seen that peneplain relicts have been better preserved and have lower altitudes north of the NMF trace. This suggests that the relicts correspond to either two different generations of peneplain or to a single peneplain affected by the downthrown movement of the NMF northern wall. On the assumption that the latter option is correct and given the northward dip of this fault, this offset indicates normal faulting. To shed light on this aspect, we performed a topographic analysis by producing a slope map of the area and by drawing topographic cross sections perpendicular and parallel to the NMF.

The slope map derived from a $30 \mathrm{~m}$ DEM shows the location and geometry of the peneplain relicts (Fig. 8). It should be pointed out that some of the elevated sub-horizontal zones recognisable in the study area correspond to the bottoms of glacial cirques or to hanging glacial palaeovalleys and must not be confused with the oldest peneplain (Guinnell and Calvet, 2006). Topographic profiles that run perpendicular and parallel to the NMF helped us to understand the geometry, altitude range and relationships of the surface relicts (Fig. 8). The profiles reveal a slight tilt of the downthrown peneplain envelope towards the SE, i.e. towards the eastern edge of the fault. This geometry contrasts with the sub-horizontal envelope of the 
relicts at the southern wall. N-S profiles show that the offset of the peneplain is at a maximum at Porèra $(515 \mathrm{~m})$ and gradually diminishes to the West.

One observation kept us from considering the possibility of two different generations of peneplains. On the one hand, the break in altitude only occurs along the trace of the NMF. This could be attributed to the location of the palaeo-Garona river following the trace of the Alpine fault with the result that the spatial correspondence between the break of the slope and the fault trace could be related to differential erosion along the weakened fault zone. However, the downthrown surfaces are tilted towards the NMF, which agrees with a normal fault reactivation. Accordingly, peneplain relicts represent the major geomorphic markers displaced by the NMF. The observed offset indicates a downthrown movement of the northern wall of the fault as suggested by the northfacing faceted spurs (Figs. 4 and 7).

\subsection{Facetd spurs}

The faceted spurs associated with the NMF dip $30-40^{\circ}$ to the North. They are up to 450 $\mathrm{m}$ high and are separated by valleys, which are perpendicular to the fault and have been excavated $400 \mathrm{~m}$ below the downthrown peneplain (Figs. 4 and 7). Faceted spurs at Malh de Vivers and Mieidia are characterised by more rectilinear profiles. The higher altitude of these facets and their location in relation to the drainage network indicate that they were less affected by glacial erosion. This is consistent with the lack of evidence of glacial erosion on the surfaces below these facets. By contrast, the spurs south of the Porèra and Prüedo areas are less well preserved, especially at Prüedo where three rocky glaciers are located. This degree of preservation is that expected given that these surface relicts are partially covered by till deposits. The $30-40^{\circ}$ dip of the facets is not in agreement with the $\sim 80^{\circ}$ dip of the NMF derived from geological boundaries. This discrepancy is explained by the regression of the facets. Concavity of the profiles transversal to the spurs at the Porèra and Prüedo sites together with the emplacement of rocky glaciers at the Prüedo spur reveals that they formed before the last glacial maximum and probably before Quaternary times.

The proximity and alignment of the Garona river to the faceted spurs prompted us to ask whether they could be pure erosive features related to the palaeo-Garona river incision along the Alpine fault zone. However, their relative size and geometry (Fig. 7 and 8) do not seem to be determined only by the erodability of the affected material. Despite being less preserved to the East, the spur size increases in this direction given the increasing offset observed. It therefore seems unlikely that the faceted spurs originated without a tectonic component.

\subsection{Secondary Neotectonic features}

A first approach by air-photo analysis enabled us to identify minor rectilinear scarps near the trace of the NMF (Fig. 4). The field survey of these scarps helped to distinguish those developed by gravitational deformation of the slopes (valley sides of Valarties and Aiguamoig) and those produced or modified by diferential erosion along the geological boundaries. Scarps affecting the glacial till and restricted to the downthrown peneplain relicts were selected as possibly tectonic features pre- or postdating last glacial maximum. These scarps are 300-500 m long and 5 to $20 \mathrm{~m}$ high, trend approximately parallel to the NMF trace and dip both north and south.

\subsection{The North Maladeta Fault and associated Prüedo Basin}

The trace of the Alpine NMF is enhanced by the presence of highly deformed PermoTriassic reddish lutites (Mattauer and Seguret, 1966; Kleinsmiede, 1969). These rocks crop out exclusively at Prüedo, south of the NMF trace (Fig. 3a) and are unique given that no other Mesozoic rocks have been preserved in this sector of the Axial Zone. They have been interpreted as affected by Alpine deformation along the "Gavarnie thrust" (García Sansegundo, 1992). Two decametric lenses of matrix-supported breccias, which are derived from these lutites, are embedded in the glacial till found at the toe of the fault at Prüedo. Although these breccias could be interpreted as glacial deposits, their proximity to the source area suggests that they might have formed by sliding along the faceted spur to the South, which would have been steeper in the past.

The location of the faceted spurs and the step offseting the peneplain relicts allow us to trace the geomorphic expression of the NMF for a total length of $17.5 \mathrm{~km}$ (Fig. 4) as a set of three E-W trending segments. This trace does not follow strictly the Alpine thrust separating the 
Nogueres and Orri units as mapped or defined by Majeste-Menjouleas (1979), Muñoz, (1988) and García Sansegundo (1992). The central segment shows a right and left stepping geometry with the eastern and western segments, respectively. The hanging wall downthrow indicates that the Alpine reverse NMF has been inverted in recent times as a normal fault. This tectonic inversion implies reactivation of the structure under a tensile or transtensional regime after formation of the Pyrenean peneplain. This activity continued for a period of time long enough to accumulate the observed offset (Fig. 7a).

Three outcrops of non-consolidated layered detritic deposits (henceforth Prüedo deposits) are found next to the NMF trace on the hanging-wall of the fault at Prüedo and Porèra (site 1, 2 in Fig. 4). The deposits overlie Variscan basement rocks and are covered by a glacial till of variable thickness. At site 1 , just beneath the toe of the faceted spurs, the Prüedo deposits are bounded laterally to the South by granitic rocks belonging to the Maladeta Batholith. The granites crop out in cliffs and are weathered as arkose. This weathering suggests that these rocks had been exposed to a warmer climate in pre-Quaternary times.

Discrete scarps affecting the peneplain surfaces have been observed at Prüedo and Porèra and could correspond to recent faults bounding the Prüedo deposits to the North. These observations suggest that the sediments are confined within a small tectonic basin originated by the recent activity of the NMF. Earlier descriptions of the Prüedo deposits at site 2 were made by De Sitter (1954), Jelgersma (1957), Kleinsmiede (1960) and Vilaplana et al. (1986). Only Jelgersma (1957) suggested that the deposits could have been trapped in a lake owing to subsidence of a small basin related to the fault activity, although there is no specific reference to active tectonics in her hypothesis. The relationship of these deposits to the Pyrenean peneplain is discussed by De Sitter (1954), who interpreted the sediments as filling a gorge incised in the peneplain. In contrast, Kleinsmiede (1960) surmises that the deposits are older than the peneplain because the top of the sequence approximately matches the height of the erosional surface $(2000 \mathrm{~m})$. However, as discussed above, the peneplain at Prüedo has been modified by ice sheets. As a result, the Prüedo deposits and the glacial till on top of them are at the same level as the peneplain relict. We did not find sufficient field evidence to determine the chronological relationship between the Prüedo deposits and the erosional surfaces.

4.4 Prüedo deposits

Detailed observations of the Prüedo sequence were made at two creeks, Els Estrets (site 1) and Barranc del riu del Merder (site 2), draining to the Valarties and Aiguamoig rivers, respectively. Outcrops occur in vertical cliffs next to gullies, where the material is affected by rotational landslides and earthflows. Correlation of these outcrops allowed us to identify a $\sim 200$ $\mathrm{m}$ thick upwards fining succession. Well rounded and coarse basal conglomerates are overlain by alternating micro-conglomerates, sand and silt layers. The silty layers are up to $1 \mathrm{~m}$ thick and have small sandy channels that are interbedded. The top of the sequence is dominated by lignite levels covered by a 10-30 m thick glacial till mainly made up of granitic boulders and lenses of brecciated Permo-Triassic rocks.

Lithological composition, pebble roundness, grain size distribution and sedimentary structures (channels and imbricated clasts) suggest an E-W running fluvial-palustrian system, locally fed by alluvial fans derived from the southern relief. Most of the pebbles of the basal units are rounded, and have coarse to fine grain size. They are confined to large channels and grade laterally into silty levels with minor interbedded sandy channels. This configuration suggests the existence of a main central channel that laterally migrated into a flood peneplain. The pounding or deepening of the system is reflected in a fining upwards sequence of sediments alternating with up to $20 \mathrm{~cm}$ thick lignite layers, which is characteristic of a cyclic subaquous deposition. Climate change and recurrent tectonic activity causing periodic damming could account for the alternating character of this sequence.

Based on a palynologic correlation with the Estavar deposits of the Cerdanya basin (Eastern Pyrenees), Jelgersma (1957) proposed that the sequence was probably formed during the Vindobonian (Late Miocene). More recent dating of the Estavar deposits based on the fossiliferous mammal content (Agustí and Roca, 1987) indicates a Vallesian age, which according to Agustí et al. (2001) is constrained between 11.1 and 8.7 Ma. Considering this age 
for the Estavar deposits and assuming the correlation made by Jelgersma, the Prüedo deposits would be Vallesian in age.

\section{Deformation related to the NMF activity. Neotectonic implications}

Layers in the Prüedo detritic sequence are mainly horizontal and do not show any sign of internal deformation with the exception of site 1, where the whole outcrop dips approximately $15^{\circ}$ towards the Valarties Valley. Minor fault plains with striations indicate that the material is affected by mass movements.

No clear evidence of recent surface rupturing along the trace of the fault could be found so far. In the vicinity of the NMF, the rivers flow through chaotic accumulations of boulders or cut into bedrock of resistant lithology. In the former case, recognition of a scarp in the riverbed is particularly difficult, given the irregular topography of the boulder accumulations and the relatively small slip rates expected for faults in this area. In the latter case, the high erosion rates of the river can easily smooth and even obliterate any possible fault scarp generated in recent times. On the other hand, the slopes of the valleys are mantled with debris cones and debris talus and are often affected by rock falls where the basement crops. Summarizing, it is difficult to recognise active faulting in any place other than the elevated peneplain relicts, the oldest landforms preserved in the landscape.

In conclusion, we consider that the faceted spurs together with the offset of the elevated peneplain and the formation of the Prüedo basin constitute the most direct evidence of the recent NMF reactivation as a normal fault.

Analogous displacements of peneplain relicts in the Eastern Pyrenees have been reported by Calvet (1985) and Briais et al. (1990) in the Cerdanya basin and by Arthaud and Pistre (1993) in the Millas Massif. In contrast to what it is observed in the Maladeta Massif, where a single offset has been detected, the peneplain surface in the Millas Massif is affected by a set of orthogonal faults that compartmentalize the surface into stepped domains. The formation of the recent scarps of the Millas Massif is attributed to a period of tectonic relaxation after the Miocene.

\section{Geophysical approach: the AMT survey.}

Except for range-scale seismic profiles performed in nearby transects (Choukroune and ECORS team, 1989, Muñoz 1992, Sibuet et al. 2004), no detailed geophysical explorations providing information on the tectonic structure of the area have been carried out to date.

Performance and interpretation of an audiomagnetotelluric survey perpendicular to the NMF at the Prüedo site (location in Fig. 4 and 8) enabled us to recognise the NMF as a major discontinuity and revealed the geometry of the Prüedo basin. From this geometry, the structure of the basin could be deduced and thus linked to the recent NMF activity as a normal fault.

6.1 The AMT method

Audiomagnetotellurics (AMT) is a passive electromagnetic technique that works in the frequency domain and allows us to obtain the resistivity distribution of the subsurface. The fundamentals of AMT are common to the magnetotelluric method. At the surface of the Earth, simultaneous measurements of the temporal fluctuations in the natural electromagnetic field are recorded, allowing us to determine the electrical resistivity at depth (Simpson and Bahr, 2005). Variations in the resistivity value are related to changes in rock properties such as lithology, structure, porosity and fluid content.

Stratagem equipment from Geometrics, which works in the frequency range between $10^{5}$ and $10^{1} \mathrm{~Hz}$, was used to acquire thirteen AMT measurements along the Prüedo section (Fig. 4). This range of frequencies enables us to study depths from $10 \mathrm{~m}$ up to $3 \mathrm{~km}$ in a resistivity range between $10 \Omega \cdot \mathrm{m}$ and $1000 \Omega \cdot \mathrm{m}$. The maximum separation between continuous sites was $220 \mathrm{~m}$ and the minimum $25 \mathrm{~m}$, the latter corresponding to sites closer to the surface trace of the NMF.

6.2 Data processing and subsurface modelling

The impedance tensor is the complex transfer function that relates simultaneous variations in electric and magnetic fields. AMT models were created using the inversion algorithm proposed 
by Siripunvaraporn and Egbert (2000) modified by Pedersen and Engels (2005). This model uses impedance tensor determinant components. The determinant of the impedance tensor provides a suitable compromise that allows for a good data fit, while at the same time resolving reasonably well both resistive and conductive structures along the profile. The determinant mode has been successfully tested in several studies (Pedersen and Engels, 2005; Linde and Pedersen, $2004 \mathrm{a} / \mathrm{b})$. In the inversion process, a $100 \Omega \cdot \mathrm{m}$ half-space initial model was considered and an error floor of $10 \%$ for the resistivity and $5 \%$ for the phase was assumed. The RMS misfit of the final model is 3.2. (a RMS misfit of unity signifies a fit to within statistical tolerances with assumed errors of $10 \%$ for the apparent resistivity and $5 \%$ for the phase). Figure 9a shows the comparison between data and model responses. Owing to the resolution of the model in depth from our frequency range, only results from the first kilometre of the crust were considered.

\subsection{Geological interpretation derived from the AMT model and field observations}

Analysis of the model by comparing the resistivity distribution with the exposed geology allows us to distinguish several zones (labeled a-d in Fig. 9b):

a) In the southern part, a major vertical resistivity contrast is associated with the NMF zone. The zone is characterized by a 50-100 m thick fringe made up of moderate-low resistivity rocks $(25-120 \Omega \cdot \mathrm{m})$ at depths greater than $200 \mathrm{~m}$ and very high resistivity rocks $(\sim 300 \Omega \cdot \mathrm{m})$ at shallower levels. The latter materials might be either lenses of Permo-Triassic highly metamorphosed detritic rocks involved in the Gavarnie thrust or faulted Maladeta granitic rocks. Continuation in depth of this structure is observed down to approximately $800 \mathrm{~m}$, which is the resolution depth achieved by this model. This lateral change is well determined by the AMT data, and cannot be considered as an edge effect given that there are sites on both sides of the fault and the lateral sensitivity of the tensorial magnetotelluric data. The inferred data allow us to characterise the NMF with a $\sim 80^{\circ}$ dip to the North, which is in accordance with the dip derived from the geological boundaries.

b) A southern-central shallow part consisting of a lower resistivity superficial zone $(<25$ $\Omega \cdot \mathrm{m}$ ) of approximately $1 \mathrm{~km}$ in length is detected immediately north of the NMF. This volume corresponds to the sedimentary infill of the Prüedo tectonic basin. The southern and northern vertical boundaries of this conductive zone correlate with two E-W striking Alpine faults observable in the field, the NMF being the southern one. Henceforth, the northern fault will be termed the Tredós fault.

As can be appreciated in the model, this zone is segmented into three blocks by the presence of vertical discontinuities. These blocks, interpreted as three different sub-basins, are progressively shallower to the North and have graben and half-graben geometries. From south to north, the base of these basins can be roughly located at $210 \mathrm{~m}, 100 \mathrm{~m}$ and $60 \mathrm{~m}$ below the surface, respectively. The floor of the basin, especially in the northernmost sub-basin, is planar and has a uniform dip towards the NMF. This tendency is in agreement with the tilt towards the NMF observed in the peneplain relicts of the downthrown wall (Fig 8) and thus suggests that the base of the Prüedo basin corresponds to the peneplain relict, sealed by the detritic sequence at this zone. The location of the deeper base next to the NMF agrees with the presence of a thicker sequence of detritic deposits at this area (site 1 in Fig. 3 and 4).

As observed in the field, the sedimentary infill corresponds to detritic deposits. Low resistivity is attributed to the high water content of the detritic deposits and to the high content of conductive clays in the predominantly silty layers. At the surface, small patches of very high resistivity $(\sim 300 \Omega \cdot \mathrm{m})$ rocks overlying the basin infill can be related to the glacial till cover, mainly composed of granitic boulders and reaching a maximum of $50 \mathrm{~m}$ thickness.

c) The central part is characterized by an upper zone of moderate to high resistivity ( $300 \Omega \cdot \mathrm{m})$, directly underlying the sedimentary infill, and by a lower, highly conductive zone $(\sim$ $10 \Omega \cdot \mathrm{m}$ ) below $400 \mathrm{~m}$ depth. By comparing the results of the model with the geology of the area, a more resistant material corresponding to granodiorites is identified. This is underlain by lower resistivity rocks, probably Devonian limestone, which crop out immediately to the North of the basin and are affected by karstification. The limestone also crops out at the peneplain East and West of Prüedo. 
d) To the north of the Tredos fault, a low resistivity zone $(\sim 10 \Omega \cdot \mathrm{m})$ corresponding to outcropping limestone is identified. As inferred from the model, this fault is associated with a vertical fringe of moderate resistivity $(25-35 \Omega \cdot \mathrm{m})$ representing a vertical contrast in properties between the granitic body and the limestones to the South. This lateral resistivity contrast is well controlled by the presence of soundings on both sides of the fault. While there is no such contrast at depths below $400 \mathrm{~m}$, where the limestone rocks are found on both sides of the fault, the structure is still evident because of its higher relative resistivity. Although this fault is characterized by a bedrock scarp, its short length does not correspond to a primary tectonic rupture. Differential erosion or secondary tectonic faulting could account for the origin of the surface bedrock scarp.

The geological interpretation is represented in figure 9c. Rocks to the south of the NMF correspond to the Maladeta Batholith and its aureole, and belong to the Orri Unit. Rocks to the North of the NMF are part of the Tredos Batholith and its aureole, and belong to the Nogueres Unit.

Minor faults defining grabens are not observed below the first $400 \mathrm{~m}$ of crust. Based on their relative position, these faults correspond to NMF conjugated faults. The base of the granite is displaced only by a few tens of meters by these faults. These faults connect at the surface with topographic scarps parallel to the NMF (Fig. 4), suggesting that these surface features are secondary active tectonic scarps rather than glacial landforms or erosive scarps.

\section{NMF source parameters}

\subsection{Slip rate}

Based on pollen analysis, the age of the Prüedo deposits has been correlated with the Vallesian (11.1-8.7 Ma) Estavar deposits (Cerdanya basin). A rough estimation of the minimum slip-rates associated with the recent NMF activity can be done by assuming this age and by considering that the NMF has been active as a normal fault since that time. The formation of the Prüedo basin and the associated deposits provides a minimum age for the genesis of the peneplain.

The maximum vertical offset of the surfaces is observed at the Porèra transect $(515 \mathrm{~m})$. Although some discrete outcrops of the Prüedo deposits have been found at Porèra, their higher elevation and their reduced outcrop dimensions compared with the deposits at Prüedo suggest that the graben was shallower in this area. This indicates that the Prüedo area is the location where maximum displacement has been recorded. The maximum vertical throw accommodated by the NMF during this period can be approximated by adding the depth of the tectonic graben below the surface envelope to the surface envelope offset. This yields an estimate of $\sim 290 \mathrm{~m}$ for the graben depth, which when added to the $440 \mathrm{~m}$ surface vertical offset at the Prüedo transect results in a maximum vertical throw of $\sim 730 \mathrm{~m}$. Averaged since Vallesian times, this vertical displacement gives a vertical slip-rate in the range of $0.06-0.08 \mathrm{~mm} / \mathrm{a}$. This is a rough estimate of the vertical slip-rate, which does not take into account factors such as the enhanced erosion on the uplifted surfaces or the deepening of the graben by fluvial erosion.

Linear markers perpendicular to the NMF do not show any evidence of being displaced. In order to make a first approximation to the NMF source parameters, we took the throw-rate as the slip-rate of the fault. By considering the $80^{\circ}$ dip inferred from the AMT survey, the dip displacement results in $741 \mathrm{~m}$ and the real slip-rate only increases by some $0.001 \mathrm{~mm} / \mathrm{a}$, which is below the sensitivity of the calculations.

\subsection{Surface Rupture Length and Rupture Width}

Considering the $17.5 \mathrm{~km}$ geomorphological trace as the surface rupture length (SRL) of the maximum earthquake, a maximum $\mathrm{Mw}=6.5 \pm 0.66$ is obtained through Wells and Coppersmith (1994) relationships for normal faults. Given that the Mw estimated for the 1373 event (Olivera et al. 2006) is within this range and that the NMF is the only active structure described to date in the area of the 1373 earthquake epicentre, it is reasonable to assume that this earthquake corresponds to the maximum earthquake associated with the NMF. The rupture width (RW) of this event is unknown but should be in the range of the 10-20 km hypocentral depth estimated for the 1373 earthquake (Olivera et al. 2006), which is in agreement with the 10-15 km RW derived from Wells and Coppersmith (1994) regressions for $\mathrm{Mw}=6.2-6.5$ earthquakes along 
normal faults. We consider the $12 \mathrm{~km}$ maximum depth for the recorded microseismicity below the Maladeta Massif to be a reasonable value for the rupture area lower boundary. According to Souriau and Pauchet (1998), this value corresponds to the depth of the seismogenic crust in the area.

Following Wells and Coppersmith (1994) relationships, $16.5 \mathrm{~km}$ and $4.9 \mathrm{~km}$ of subsurface rupture length (RLD) are expected for the 1373 and the 1923 events, respectively.

The $17.5 \mathrm{~km}$ geomorphological trace length of the NMF is composed of three different segments. Owing to its location and length, only the westernmost segment can be associated with the $\mathrm{Mw}=5.31923$ earthquake. From the available data, four different scenarios concerning the source location of the 1373 and 1923 can be envisaged: a) that both earthquakes have been produced by the NMF, b) that only the 1373 was produced by the NMF and the 1923 earthquake was generated by a blind secondary fault, c) that only the 1923 has been produced by the NMF and the 1373 has been generated by an unknown fault, d) that any of these earthquakes have been generated by the NMF.

Since so far, there has not been found any geological evidence for other active faults in the area, we consider c) and d) scenarios as very unlikely.

Concerning the possibility b), that the 1923 event was generated by a secondary fault, the proximity of that hypothetic fault to the NMF would lead to think that both faults work as a complex system so that case b) could be considered as equivalent to case a). To the type of approach followed through this work, it does not pose a great difference to consider the 1923 as produced by a different fault branched in depth to the main structural feature or by a segment of the NMF that does not reach the surface.

On the other hand, option a) has two possible scenarios: a.1) that both earthquakes were produced by the rupture of two consecutive segments of the NMF, implying that the NMF total RLD could reach $23-25 \mathrm{~km}$. In this case, only $17.5 \mathrm{~km}$ of the total fault length would have geomorphologic expression; and a.2) that the two earthquakes have been produced by the rupture of coincident segments.

7.3 Seismic cycle and Recurrence interval

The lack of unequivocal evidences does not allow obtaining any conclusion on the NMF rupture behaviour. We consider that none of possibilities a.1, a.2 and $\mathbf{b}$ can be neglected and wish to highlight how relevant they are in the evaluation of the NMF seismic cycle; If both events are generated by the rupture of coincident segments of the NMF, we would not expect this fault to have characteristic earthquake behaviour.

Wells and Coppersmith (1994) regression between $\mathrm{Mw}$ and maximum displacement (MD), $\log (\mathrm{MD})=-5.46+0.82 * \mathrm{Mw}$, suggests that $\mathrm{a} \sim 77 \mathrm{~mm} \mathrm{MD}$ is expected for a $\mathrm{Mw}=5.3$ event. Assuming that this was the maximum displacement of the 1923 event, this value is considerably greater than the $44 \mathrm{~mm}$ slip accumulated during the 550 years span between the 1373 and the 1923 earthquakes as derived from the $0.08 \mathrm{~mm} / \mathrm{yr}$ maximum NMF slip rate obtained above. In that case, again, we could explain the misfit a) by considering that the 1923 earthquake was generated by a secondary fault, b) by suspecting that the cumulated slip along the NMF was not completely released by the 1373 event leading to a greater displacement along its westernmost sector in the 1923 earthquake or c) by concluding that the average slip rate along the NMF differs from the present day rate, which in that case should be greater than $0.08 \mathrm{~mm} / \mathrm{yr}$. Although there is little knowledge on the average present day slip-rates for faults in the Pyrenees, the tectonic context lead to expect slip-rates lower than this value rather than greater. For this reason, we consider option c) as very improbable.

In case the NMF do not have characteristic earthquake behaviour, it would be of little value to calculate its recurrence interval. Nevertheless, in order to obtain a first approach to the possible fault seismic parameters, we have proceeded to estimate the recurrence interval ( $\mathrm{Tr})$ by considering that the fault do behave according to a seismic cycle with periodic ruptures of $\mathrm{Mw}=6.5$ for which the field derived SRL and the 1373 estimated magnitude (Olivera et al. 2006) are in accordance.

As stated above, the slip-rate of the NMF is comprised between 0.08 and $0.06 \mathrm{~mm} / \mathrm{a}$. Assuming the $12 \mathrm{~km}$ seismogenic crust thickness as the rupture zone lower boundary and considering the $\sim 80^{\circ}$ dip of the fault, a rupture width of $12.2 \mathrm{~km}$ is expected. Using these values, $3 \times 10^{10} \mathrm{Nm}^{-2}$ as 
the shear modulus of elasticity $(\mu)$ of the crust and the field derived $17.5 \mathrm{~km} \mathrm{SRL}$, a moment rate $\left(\mathrm{M}_{\mathrm{o}}{ }^{\mathrm{g}}\right)$ in the range of $(5.04-3.78) \times 10^{14} \mathrm{~N}-\mathrm{m} / \mathrm{a}$ is obtained according to Brune (1968). Two different approaches were considered to calculate the seismic moment expected for an event $\left(\mathrm{M}_{\mathrm{o}}{ }^{\mathrm{e}}\right)$ of magnitude $\mathrm{Mw}=6.5$. Hanks and Kanamori (1979) empirical relationship between $\mathrm{M}_{\mathrm{o}}{ }^{\mathrm{e}}$ $(\mathrm{N}-\mathrm{m})$ and $\mathrm{Mw}, \log \mathrm{M}_{\mathrm{o}}{ }^{\mathrm{e}}=1.5^{*} \mathrm{Mw}+9.1$, leads to $\mathrm{M}_{\mathrm{o}}{ }^{\mathrm{e}}$ of $7.10 \times 10^{18} \mathrm{~N}-\mathrm{m}$. However, from the definition of the seismic moment, $\mathrm{M}_{\mathrm{o}}=\mu^{*} \mathrm{AD} \mathrm{L}^{*} \mathrm{~W}$, a much lower value $\left(\mathrm{M}_{\mathrm{o}}{ }^{\mathrm{e}}=3.20 \times 10^{18} \mathrm{~N}\right.$ $\mathrm{m}$ ) is obtained. This value results from considering the average displacement (AD) of $0.5 \mathrm{~m}$ derived from Wells and Coppersmith (1994) and $17.5 \mathrm{~km}-12.2 \mathrm{~km}$ values for L and W. Choosing among these $\mathrm{M}_{0}{ }^{\mathrm{e}}$ values has important consequences in the estimation of the $\mathrm{Tr}$; Following the approach proposed by Wesnousky (1986) and the estimated $\mathrm{M}_{\mathrm{o}}^{\mathrm{g}}$ range of (5.04 3.78) $\times 10^{14} \mathrm{~N}-\mathrm{m} / \mathrm{a}, \quad$ a $\mathrm{M}_{0}{ }^{\mathrm{e}}=7.10 \times 10^{18} \mathrm{~N}-\mathrm{m}$ leads to a $\mathrm{Tr}=18.8-14.1$ ka while a $\mathrm{M}_{0}{ }^{\mathrm{e}}=3.20 \mathrm{x}$ $10^{18} \mathrm{~N}-\mathrm{m}$ would result in a $\mathrm{Tr}=6.25-8.33 \mathrm{ka}$. This latter range of $\mathrm{Tr}$ is more conservative and thus, is the one that should be considered in the evaluation of the seismic hazard of the area.

\section{The North Maladeta Fault activity and the Present state of stress in the Pyrenees.}

Our findings suggest that the NMF is, at present, a seismogenic fault and that it has been active under a tensional regime since the Late Miocene. The continuation of this tectonic regime has led to more than $700 \mathrm{~m}$ vertical offset, which suggests that activity as a normal fault could have continued until the Present. These data improve our understanding of the active faults in the Pyrenees. However, given that no focal mechanism has been calculated for the 1923 earthquake and given the lack of field evidence of historical ruptures along the fault, the question concerning its present day faulting mechanism remains unresolved.

As stated in section 2, available seismotectonic data for the Central Pyrenees do not allow us to define the neotectonic stress field for the region. To determine this stress field, we widened our perspective to include the whole Pyrenean range.

Since the end of the Paleogene, the convergence between Africa and Eurasia in the Iberian Peninsula has concentrated in the Betic-Rif belt (Westaway, 1991; Capote et al., 2002). In this regard, the Pyrenees can no longer be considered as an active tectonic margin and earthquakes along the chain should be taken into account as intraplate events. Thus, interaction between stress accumulation and stress release along pre-existing structures must cause local variations in the tectonic stress field (Caputo, 2005). This could in part account for the hetereogeneity of the stress tensors derived from borehole breakouts and focal mechanisms of earthquakes during the instrumental period (Jurado and Muller, 1997; Goula et al., 1999; Souriau et al. 2001). The problem of the heterogeneity also seems to be related to the limitations of the methods used to derive the stress orientation: focal solutions are often poorly constrained owing to the inadequate geometry of the seismic network and to the fact that the complexity of the Pyrenean crust is not sufficiently considered in their calculations (Souriau et al. 2001). Despite the important improvements derived from combined studies (Nicolas et al. 1990; Souriau and Pauchet, 1998; Goula et al., 1999; Herraiz et al., 2000; Souriau et al, 2001), there is no general model for the post-collision stress evolution of the Pyrenean range to date. The data obtained using these approaches are often inconsistent and contradictory: based on geological outcrop analyses and focal mechanisms, Goula et al. (1999) maintain that the stress regime in the Eastern Pyrenees was inverted from tensional to compresional regimes in Plio-Quaternary times and that it has prevailed since then with a NNE-SSW orientation of $\sigma_{\mathrm{H} \max }$. Analysis of the instrumental seismicity of this area shows that most of the P axes are subhorizontal (Goula et al., 1999; Souriau et al. 2001). Geological indicators for the Western Pyrenees are scarce and suggest a $\sigma_{1}$ oriented NS to NW-SE (Alasset and Meghraoui, 2005; Nivière et al., 2006), which agrees with the average trend derived from the diversity of focal mechanism solutions obtained in this area. The mechanisms indicate right lateral, normal and reverse faulting with the $\mathrm{P}$ axis oriented both vertically and horizontally (Souriau et al. 2001). Thus, the main differences between the two sectors are the scarcity of focal mechanisms with the $\mathrm{P}$ axis vertical in the Eastern sector and the orientation of the $\sigma_{\mathrm{H} \max }$, which varies from NW-SE/NS (to the West) to NS/NE-SW (to East). In this regard, data seem to indicate that normal faulting is taking place only in the Western-Central sectors, which suggests that locally the $\sigma_{1}$ is subvertical. The feasibility of normal faulting at the core of the range has been widely discussed in works 
performed in the Andes (Dalmaryac and Molnar, 1981, Sebrier et al. 1985) and the Himalayas (Molnar and Tapponier, 1978; Mercier et al., 1987). As proposed by Dalmaryac and Molnar (1981) and Molnar and Lyon-Caen (1988), in the evolution of orogenic belts, the forces driving the plates together might not be sufficient to compensate for the vertical stress $\left(\sigma_{\mathrm{V}}\right)$ associated to the lithosphere, leading to temporal and spatial variations in the orientation of the maximum and minimum stresses. Thus, the lithospheric $\sigma_{\mathrm{V}}$ maximized in regions of high altitude with thick crustal roots could probably exceed the horizontal compressive strength. This could lead to localized crustal tension with associated normal faulting. Reciprocally, minimum values of lithospheric $\sigma_{\mathrm{V}}$ at the foot of the ranges are favourable for the occurrence of reverse faulting.

The Pyrenees are expected to be characterised by this stress state context given that structural and geophysical studies along the chain (Muñoz, 1992; Souriau and Granet, 1995; Ledo et al., 2000; Vacher and Souriau, 2001) show that the difference in crustal thickness from the Ebro and Aquitaine basins to the Axial Zone exceeds $40 \mathrm{~km}$. These studies also reveal that the continental lower crust of the Iberian plate is subducting down to $80-100 \mathrm{~km}$ in the area of the Maladeta Massif (Fig. 1). As a result, normal faulting along the NMF may be related to the maximum values of lithospheric $\sigma_{\mathrm{V}}$ reached in the area.

Published GPS data providing quantitative information on the Present day rate of convergence between Iberia and Eurasia (Nocquet and Calais, 2004) show that deformation across the Pyrenees does not exceed $0.5 \mathrm{~mm} / \mathrm{yr}$. Thus, the compression perpendicular to the chain is negligible compared to the compression characterising active plate boundaries such as those located in the Andes or Himalayas. For this reason, a dominant lithospheric $\sigma_{v}$ would be feasible even for values of lithospheric thickness smaller than the maximum $80-100 \mathrm{~km}$ value. It should be pointed out that local differences in exhumation between both sides of the NMF could be the cause of variations in $\sigma_{\mathrm{V}}$ and thus, exhumation and tectonic reactivation of the fault could be related.

\section{Conclusions}

In the light of our findings, the following conclusions may be drawn:

1) Macroseismic analysis of the 1923 and 1373 seismic events combined with a geomorphological study of the area suggest that the NMF is a seismogenic fault probably associated with the 1923 Vielha earthquake and that it could be considered as the possible source of the 1373 Ribagorza earthquake.

2) Geomorphological analysis of the NMF and its surroundings allowed us to identify a $17.5 \mathrm{~km}$ long fault trace with a downthrown movement of the northern block up to 730 $\mathrm{m}$, indicating a normal faulting regime. Based on the empirical relationships of Wells and Coppersmith (1994), this fault length implies a maximum potential earthquake of $\mathrm{Mw}=6.5 \pm 0.3$. This estimation must be considered in the evaluation of the seismic hazard of the area.

3) Geological understanding of the NMF neotectonic activity was significantly enhanced by an audiomagnetotelluric survey. The study revealed that the Prüedo basin structure is clearly related to normal faulting along the NMF and that its sedimentary infilling overlies relicts of the Pyrenean elevated peneplain. The age constraint for these sediments (11.1-8.7 Ma) represents a minimum age for the genesis of the elevated Pyrenean peneplain in this area as well as a maximum age for the reactivation of the NMF as a normal fault.

4) The maximum vertical slip-rate along the NMF since Late Miocene (Vallesian) is estimated between 0.06 and $0.08 \mathrm{~mm} / \mathrm{a}$.

5) The reactivation of the NMF as a normal fault is related to a tensional regime characterising the region for a period of time starting in the Late Miocene and possibly extending until the Present. Normal faulting at the core of the Pyrenean range is expected to occur owing to the generalized tectonic relaxation and to the high values of lithospheric $\sigma_{\mathrm{V}}$ associated with lithospheric subduction. 


\section{Acknowledgements}

The Spanish Ministerio de Educación y Ciencia provided funding for the EPIC project (Proyecto Nacional BTE2002-00324), for the Consolider-Ingenio 2010 programme/project "Topo-Iberia" (CSD2006-0004), and for the doctoral FPU fellowship of M. Ortuño. The Generalitat de Catalunya gave financial support to the RISKNAT group (SGR2001/ 00081). The Centre de Recerca d'Alta Muntanya (CRAM) from the Universitat de Barcelona provided facilities during the field work. Thanks are due to Carme Olivera and Teresa Susagna for sharing the macroseismic data and to Michel Sébrier and Jesús Galindo Zaldivar for their helpful comments and suggestions, which significantly improved the quality of this paper. We are indebted to Oriol Besora for his help in the field work and to Carles Martí and Patricia Ruano for their constructive discussions. We also wish to thank David García for the DEM figures and to Grant G. Buffett and G. Von Knorring for helping to improve the English text.

\section{References}

Agustí, J. and Roca, E., 1987. Sintesis Biostratigráfica de la fosa de la Cerdanya (Pirineos Orientales). Estudios Geologicos, 43 (521), 529.

Agustí, J., Cabrera, L., Garcés, M., Krijgsman, W., Oms, O. y Parés, J.M., 2001. A calibrated mammal scale for the Neogene of Western Europe. State of the art. Earth Sc. Rev., 52, 247-260.

Alasset, P.-J. and Meghraoui, M., 2005. Active faulting in the western Pyrénées (France): Paleoseismic evidence for the late Holocene ruptures. Tectonophysics, 409, 39-54.

Arranz, E., 1997. Petrología del macizo granítico de La Maladeta (Huesca-Lérida): estructura, mineralogía, geoquímica y petrogénesis. PhD Thesis Univ. Zaragoza, 319 pp.

Arthaud and Pistre, 1993. Les fractures et les paléocontraintes du granite hercynien de Millas (zone axiales des Pyrénées) : un cas d'etude de la tectonique cassante d'un aquifère de socle. Geodin. Acta 6(3), 187-201.

Babault, J., Van Den Driessche, J., Bonnet, S., Castelltort, S. and Crave, A., 2005. Origin of the highly elevated Pyrenean peneplain. Tectonics, 24 (TC2010).

Babault, J., Van Den Driessche, J., Bonnet, S., Castelltort, S. and Crave, A., 2006. Reply to comment by Yanni Gunnell and Marc Calvet on "Origin of the highly elevated Pyrenean peneplain". Tectonics, 25 (TC3004).

Bordonau, J., 1992. Els complexos glacio-lacustres relacionats amb el darrer cicle glacial als Pirineus. Dept. de Geologia Dinàmica, Geofísica i Paleontología. Universitat de Barcelona, $\mathrm{Ph} . \mathrm{D}$. Thesis, Geoforma Ediciones, Logroño, Spain. 251 pp.

Bordonau, J. and Vilaplana, J.M., 1986. Géomorphologie et tectonique récente dans le Val d'Aran (Zone axiale des Pyrénées Centrales, Espagne). Revue de Géologie Dynamique et de Géographie Physique, 27(5), 303-310.

Brune, J.N., 1968. Seismic moment, seismicity, and rate of slip along major fault zones. Journal of Geophysical Research 73, 777-784. 
Calvet, M., 1985. Néotectonique et mise en place des reliefs dans l'Est des Pyrénées; l'exemple du horst des Albère . Rev. Géol. Dyn. Géogr. Phys., vol. 26, fasc. 2, pp. 119-130.

Calvet, M., 2004. The Quaternary glaciation of the Pyrenees. In: Ehlers, J., Gibbard, P.L. (Eds.), Quaternary Glaciations - Extent and Chronology. Elsevier, pp. 119-128.

Calvet, M. and Gunnell, Y., 2006. Morphotectonic evolution of the Pyrenees: robust vs. modeldependent interpretations. Geophysical Research Abstract, European Geosciences Union General Assembly, Vienna, Austria. 275.

Capote, R., Muñoz, J.A., Simón, J.L., Liesa, C.L., Arlegui, L.E., 2002. Alpine tectonics I: the Alpine system north of the Betic Cordillera. In: The Geology of Spain, Gibbons W., Moreno, T. (Eds), The Geological Society, London, pp. 367-400.

Caputo, R., 2005. Stress variability and brittle tectonic structures. Earth Science Reviews, 70, 103-127.

Choukroune, P., ECORS team, 1989. The ECORS Pyrenean deep seismic profile reflection data and the overall structure of an orogenic belt. Tectonics, 8, 23-39.

Choukroune, P., 1992. Tectonic evolution of the Pyrenees. Annu. Rev. Earth Planet. Sci. 20, 143-158.

Dalmayrac, B. and Molnar, P., 1981. Parallel thrust and normal faulting in Peru and constraints on the state of stress. Earth and Planetary Science Letters, 55, 473-481.

De Sitter, L.U., 1954. Note préliminare sur la géologie du Val d'Aran. Liedse Geol. Meded., 18, 272-280.

De Sitter, L.U. and Zwart, H.J. 1962. Geological map of the Paleozoic of the Central Pyrenees, 1:50.000, sheet 1 Garonne. Liedse Geol. Meded., 27, 191-236.

Dubos, N., Sylvander, M., Souriau, A., Ponsolles, C., Chevrot, S., Fels, J.F., Benahmed, S., 2004. Analysis of the 2002 May earthquake in the central Pyrenees, consequences for the evaluation of the seismic risk at Lourdes, France. Geophys. J. Int. 156, 527-540.

ECORS Pyrenees Team, 1988. The ECORS deep reflection seismic survey. Nature 311,508511.

García Sansegundo, J., 1992. Estratigrafía y estructura de la zona Axial pirenaica en la transversal del Valle de Arán y de la Alta Ribagorça. Publicaciones especiales del Boletín Geológico y Minero, ITGE, 167 pp.

Gasperini, P., 2001. Boxer 3.1 (http://ibogfs.df.unibo.it/user2/paolo/www/boxer/boxer.html).

Gasperini, P., Bernardini, F., Valensise, G. and Boschi, E., 1999. Defining Seismogenic Sources from Historical earthquake Felt Reports. Bulletin of the Seismological Society of America, 89 (1), 94-110.

Giardini, D.; Grünthal, G.; Shedlock, K. M.; Zhang, P., 1999. The GSHAP global seismic hazard map, Annali di Geofisica, 42, 6, 1225-1230.

Goula, X., Olivera, C., Fleta, J., Grellet, B., Lindo, R., Rivera, L.A., Cisternas, A. and Carbon, D., 1999. Present and Recent stress regime in the eastern part of the Pyrenees. Tectonophysics, $308(4), 487-502$. 
Gunnell, Y. and Calvet, M., 2006. Comment on " Origin of highly elevated Pyrenean peneplain" by Julien Babault, Jean Van Den Driessche, Stéphane Bonnet, Sébastien Castelltort, and Alain Crave. Tectonics, 25(TC3003).

Gutiérrez, M. and Peña, J.L., 1981. Los glaciares rocosos y el modelado acompañante en el área de la Bonaigua (Pirineo de Lérida). Boletín Geológico y Minero, XCII (II), 11-20.

Hanks, T., Kanamori, H., 1979. A moment magnitude scale, J. Geophys. Res., 84, 2348-2350.

Herraiz, M., De Vicente, G., Lindo-Ñaupari, R., Giner, J., Simón, J.L., González-Casado, J.M., Vadillo, O., Rodríguez Pascua, M.A., Cicuéndez, J.I., Casas, A., Cabañas, L., Rincón, P., Cortés, A.L. and Lucini, M., 2000. The recent (upper Miocene to Quaternary) and present tectonic stress distribution in the Iberian Peninsula. Tectonics, 19(4), 762-786.

Jelgersma, S., 1957. Investigaciones palinológicas de lignitos terciarios de Cerdaña y del Valle de Arán (Pirineos españoles).Cursillos y Conferencias del Instituto Lucas Mallada, 4, 159-162.

Jurado, M.J. and Mueller, B., 1997. Contemporary tectonic stress in NE Iberia. New evidences from borehole analysis. Tectonophysics, 282(1-4), 99-115.

Kleinsmiede, W., 1960. Geology of the Valle de Aran (Central Pyrenees). Leidse Geol. Meded, $25,129-247$.

Ledo, J.J., Ayala, C., Pous, J., Queralt, P., Marcuello, A. and Muñoz, J.A., 2000. New geophysical constraints on the deep structure of the Pyrenees. Geophys. Res. Let., 27(7), 10371040 .

Linde, N., Pedersen, L., B., 2004a. Evidence of electrical anisotropy in limestone formations using the RMT technique, Geophysics, 69, 909-916, doi:10.1190/1.1778234.

Linde, N., Pedersen, L., B., 2004b. Characterization of a fractured granite using radiomagnetotelluric (RMT) data, Geophysics, 69, 1155-1165, doi:10.1190/ 1.1801933.

Majeste-Menjouleas, C., 1979. Structure du Paléozoïque dans le Nappe alpine de Gavarnie (Pyrénées centrales) : Influence de la configuration du socle. Bull. Soc. Geol. France, Paris, (7), 495-499.

Mattauer, M., Seguret, M., 1966. Sur le style des deformations tertiaires de la zone axiale hercyniene des Pyrénées. C.R. somm. Soc. Géol. Fr., Paris, 1, 10-13.

Mercier, J.-L., Armijo, R., Tapponnier, P., Carey-Gailhardis, E., Lin, H.T., 1987. Change from Late Tertiary compression to Quaternary extension in Southern Tibet during the India-Asia collision. Tectonics 6 (3), 275- 304.

Molnar, P. and Tapponnier, P., 1978. Active tectonics of the Tibet. Journal of Geophysical Research, v. 83, 5361-5374.

Molnar, P. and Lyon-Caen, H., 1988. Some simple physical aspects of the support, structure, and evolution of mountain belts. Geological Society of America Special Paper, 218, 179-207.

Moya, J., Vilaplana, J.M., 1992. Tectónica reciente en el Macizo de la Maladeta, sector del Alto Esera (Pirineo Central). In: Cearreta, A, Ugarte, F.M. (Eds.), The Late Quaternary in the Western Pyrenean region. Servicio Editorial Universidad del País Vasco, Bilbao, Spain, 385403. 
Müller, B., Wehrle, V., Zeyen, H. and Fuchs, K., 1997. Short-scale variations of tectonic regimes in the western European stress province north of the Alps and Pyrenees. Tectonophysics, 275, 199-219.

Muñoz, J.A., 1988. Estructura de las unidades surpirenaicas en la transversal del corte ECORS. Guía de campo de la "Reunión extraordinaria ECORS-PIRINEOS", Baussens-Balaguer (Spain).

Muñoz, J.A., 1992. Evolution of a continental collision belt: ECORS-Pyrenees crustal balanced cross-section. In: Thrust Tectonics, McClay, K.R. (Ed.),. Chapman and Hall, London, pp. 235246.

NCSE-2002, Norma de construcción sismorresistente: Parte General y Edificación. Anexo al Real decreto 997/2002 de 27 de septiembre. BOE núm. 244. Sábado 11 de octubre de 2002, 35898-35967.

Nicolas, M., Santoire, J.P. and Delpech, P.Y., 1990. Intraplate seismicity: new seismotectonic data in Western Europe. Tectonophysics, 179, 27-53.

Nivière, B., Dubos-Sallée, N., Lacan, P. and Hervouët, Y., 2006. A structural model for the seismicity of the Arduy (1980) epicentral area (western Pyrenees, France). Geophysical Research Abstracts, 8.

Nocquet, J.M., Calais, E., 2004. Geodetic measurements of crustal deformation in the western Mediterranean and Europe. Pure Appl. Geophys. 161, 661- 681.

Olivera, C., Riera, A., Lambert, J., Banda, E. y Alexandre, P., 1994. Els terratrèmols de l'any 1373 al Pirineu. Efectes a Espanya i França. Servei Geològic de Catalunya, 220 pp.

Olivera, C. and Fleta, J., 1996. Analysis of Microearthquakes (1986-1993) in Vielha Area, Axial Zone of the Central Pyrenees.European Seismological Commision, XXV General Assembley, Reykjavik, Iceland. 288-293.

Olivera, C., Redondo, E., Lambert, J., Riera Melis, A. and Roca, A., 2006. Els terratrèmols dels segles XIV i XV a Catalunya. Institut Cartogràfic de Catalunya, Monografies n³0, 407 pp.

Ortuño, M., Perea, H., Masana, E. y Santanach, P. (2004): La falla del norte de la Maladeta, ¿fuente sísmica del terremoto de Vielha (19 de Noviembre de 1923)?. Geotemas-VI Congreso Geológico de España, Zaragoza, 12-15 julio 2004, 6(3), 171-174.

Pallàs, R., Rodés, A., Braucher, R., Carcaillet, J., Ortuño, M., Bordonau, J., Bourlès, D., Vilaplana, J.M., Masana, E. and Santanach, P., 2006. Late Pleistocene and Holocene glaciation in the Pyrenees: a critical review and new evidence from 10Be exposure ages, south-central. Quaternary Science Reviews, 25, 2937-2963.

Pedersen, L. B., and Engels, M., 2005. Routine 2D inversion of magnetotelluric data using the determinant of the impedance tensor, Geophysics, doi:10.1190/ 1.1897032.

Pous, J., Muñoz, J.A., Ledo, J.J. and Liesa, M., 1995. Partial melting of subducted continental lower crust in the Pyrenees. Journal of the Geological Society, London, 152, 217-220.

Rebaï, S., Philip, H. and Taboada, A., 1992. Modern tectonic stress field in the Mediterranean region: evidence for variation in stress directions at different scales. Geophys.J.Int., 110, 106140. 
Sébrier, M., Mercier, J.L., Mégard, F., Laubacher, G., Carey-Gailhardis, E., 1985. Quaternary normal and reverse faulting and the stress in Central Andes of South Andes. Tectonics, 1985, 4(7), 739-780.

Sibuet, J., C., Srivastava, S., P., Spakman, W., 2004. Pyrenean orogeny and plate kinematics. J. Geophys. Res., 109, B08104, doi:10.1029/2003JB002514

Simpson, F. and Bahr, K., 2005. Practical Magnetotellurics, Cambridge University Press, 2005, $270 \mathrm{pp}$.

Siripunvaraporn, W., and Egbert, G., 2000. An efficient data-subspace inversion method for 2-D magnetotelluric data. Geophysics, 65; 3, 791-803.

Souriau, A. and Granet, M., 1995. A tomographic study of the lithosphere beneath the Pyrenees from local and teleseismic data. Journal of Geophysical Research, 100(B9), 18117-18134.

Souriau, A. and Pauchet, H., 1998. A new synthesis of Pyrenean seismicity and its tectonic implications. Tectonophysics, 290, 221-244.

Souriau, A., Sylvander, M., Rigo, A., Fels, J.-F., Douchain, J.-M. and Ponsolles, C., 2001. Sismotectonique des Pyrénées: principales contrainters sismologiques. Bull.Soc.géol.France, 172(1), 25-39.

Susagna, T., Roca, A., Goula, X. and Batlló, J., 1994. Analysis of Macroseismic and Instrumental Data for the Study of the 19 November 1923 Earthquake in the Aran Valley (Central Pyrenees). Natural Hazards, 10, 7-17.

Vacher, P. and Souriau, A., 2001. A three-dimensional model of the Pyrenean deep structure based on gravity modelling, seismic images and petrological constrains. Geophys.J.Int., 145, 460-470.

Vilaplana, J.M., 1983. Estudi del glaciarisme quaternari de les altes valls de la Ribagorça. Dept. de Geomorfologia i Tectònica, PhD Thesis, Universitat de Barcelona, 322 pp.

Vilaplana, J., Serrat, D., Bordonau, J., 1986. Formaciones sedimentáreas cuaternarias de origen glaciar en el Pirineo: Tills, sedimentos glaciolacustres y glaciofluviales. In: Amadon, P., Cabrera, L. (Eds).Guía de las excursiones: XI Congreso español de sedimentología, Barcelona, $1.19-1.21$

Wells, D.L. and Coppersmith, K.J., 1994. New empirical relationships among magnitude, rupture length, rupture area and surface displacement. Bull.Seismol.Soc.A., 84, 974-1002.

Wesnousky, S.G., 1986. Earthquakes, quaternary faults and seismic hazard in California. Journal of Geophysical Research, 91(B12), 12587-12631.

Westaway, R., 1991. Present-day kinematics of the plate boundary zone between Africa and Europe, from the Azores to the Aegen. Earth and Planetary Science Letters, 96, 393-406.

Zandvliet, J., 1960. The geology of the upper Salat and Pallaresa valleys, Central Pyrenees, France/Spain. Liedse Geol. Meded., 25. 1-127.

Zwart, H.J. 1979. The Geology of the Central Pyrenees. Liedse Geol. Meded., 50, 74 pp. 


\section{Figure captions}

Figure 1. A) Structural division of the Pyrenees and location of the Maladeta Batholith, the Adour Fault (AF) and the North Maladeta Fault (NMF). B) ECORS seismic cross section: The NMF is a segment of the northern dipping part of the Gavarnie thrust and corresponds to the structural division between the Aran Valley domain (metasedimentary sequences) and the Alta Ribagorza domain (Maladeta granodioritic intrusion and metasedimentary rocks forming the metamorphic aureole) Light gray corresponds to upper crust and dark gray for lower crust. N, O and R corresponds to Nogueres, Orri and Rialp units, respectively. Both figures are modified from Muñoz (1992).

Figure 2. Historical and instrumental seismicity in the Pyrenean range. Earthquakes with maximum intensity, $I_{\max } \geq V$ are represented. Ribagorza 1373 and Vielha 1923 earthquakes that occurred in the study area are shown (data from IGN, 2006, SisFrance, 2002 and Olivera et al., $2006)$ as well as the focal solutions for events that occurred in the nearby area $(11.03 .1969, \mathrm{M}=$ 4 from Nicholas et al., 1990; 24.12.1982, $M=4$ from Souriau et al. 2001; 05.08.1990, $M=3.7$ from Goula et al. 1999; 17.11.2006, $\mathrm{M}=4.5$, from IGN, 2006). Black quadrant corresponds to tension and white quadrant corresponds to compression. Background relief from GTOPO30 DEM, USGS.

Figure 3. Geology of the area (modified from Kleinsmiede 1960, Arranz 1997 and GarcíaSansegundo 1992) and location of the geomorphologic and inferred trace of the NMF. The two outcrops of Prüedo deposits studied in this work are shown as sites 1 and 2.

Figure 4. Map showing the main neotectonic features, geomorphic markers (planation surfaces) and Quaternary landforms and deposits in the proximity of the NMF. Secondary neotectonic features consist mainly of minor rectilinear scarps affecting the peneplain. The audiomagnetotelluric (AMT) section and part of the Gasperini box obtained for the 1923 earthquake are shown.

Figure 5. Intensity points for the Vielha 1923 earthquake as collected and reviewed by Susagna et al. (1994).

Figure 6. Seismic source projection obtained for the Vielha 1923 earthquake macroseismic data (Susagna et al. 1994) following the Gasperini method. The output data consist of four coordinate pairs that correspond to the vertices of a rectangle representing the rupture zone surface projection. The epicentre calculated by Susagna et al. 1994 and the maximum intensity points for the earthquake are represented together with the 1373 earthquake epicentre and part of its uncertainty area (up to $25 \mathrm{~km}$ radius). The NMF is represented for reference.

Figure 7. A) $3 \mathrm{D}$ view built from a $90 \mathrm{~m}$ DEM of the area (ICC). The NMF trace is marked with a discontinuous white line. B) Picture showing peneplain relicts displaced by the NMF at the Malh de Vivers site, where the faceted spur is more rectilinear. The picture was taken looking to the west from the location marked with an eye-symbol in figure A).

Figure 8. A) Slope map built from a $10 \mathrm{~m}$ tolerance TIN (triangulation model) of the $30 \mathrm{~m}$ DEM provided by the ICC. Peneplain relicts are marked with a discontinuous line. Faceted spurs along the NMF are delimited by a continuous line. B) Topographic profiles run parallel to the fault across the downthrown wall (1-1' to 3-3'). C) Perpendicular to the fault topographic 
profiles (A-A' to E-E') showing offset and tilting towards the fault of the peneplain envelope. The offset of the peneplain increases gradually to the East, reaching $515 \mathrm{~m}$ at Porèra.

Figure 9. Prüedo section. A) Comparison between data and model responses for the Prüedo section, located in figure 4. B) 2D AMT model. Resistivity gradients observed in the model are marked with lines. Black lines correspond to lithological changes interpreted as non-tectonic (erosive or intrusive) contacts. White lines are tectonic contacts corresponding to the main fault (NMF), the Tredós fault and secondary conjugate faults. C) Geological section derived from the integration of AMT data and field survey. 


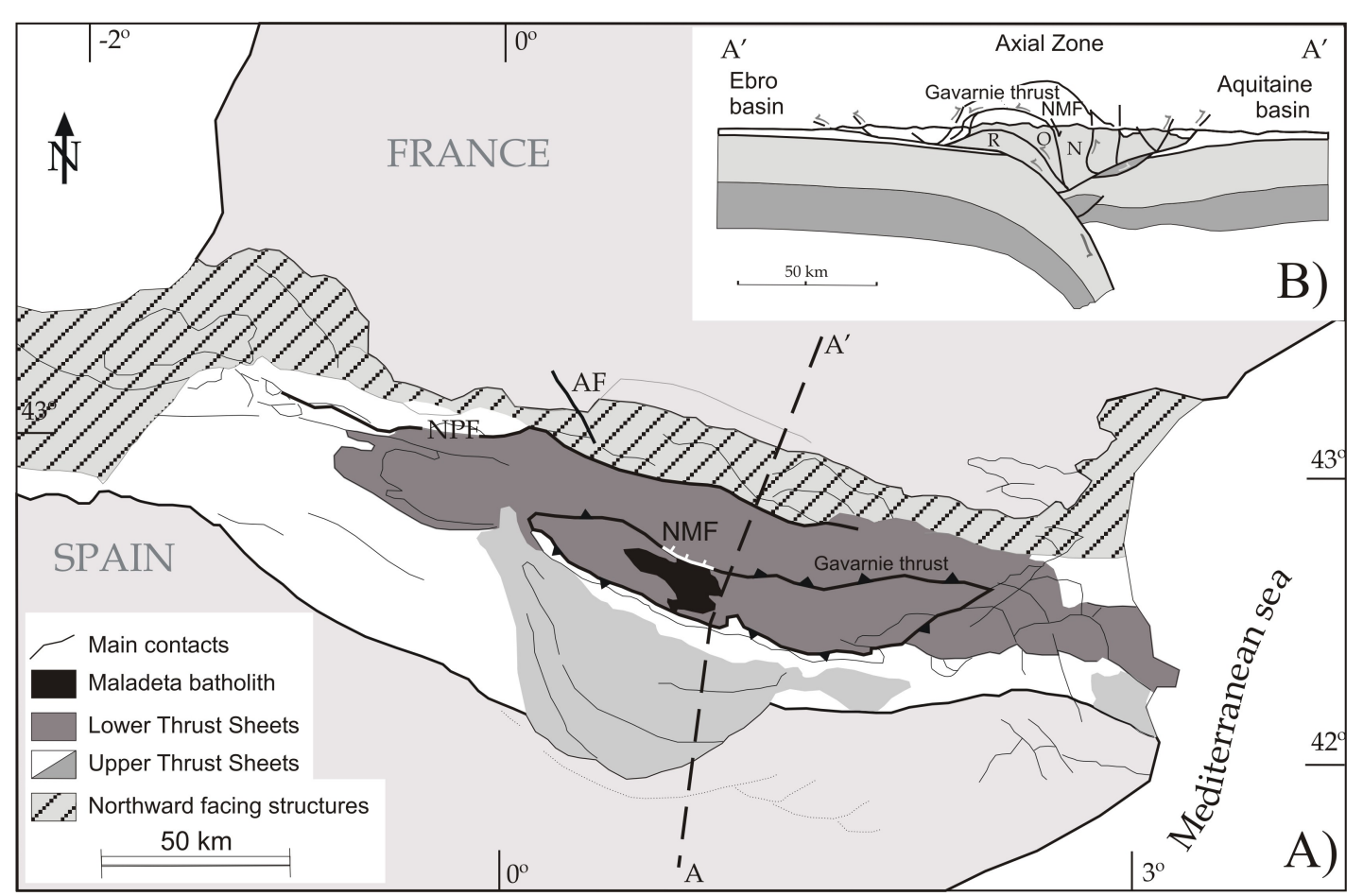

Fig 1

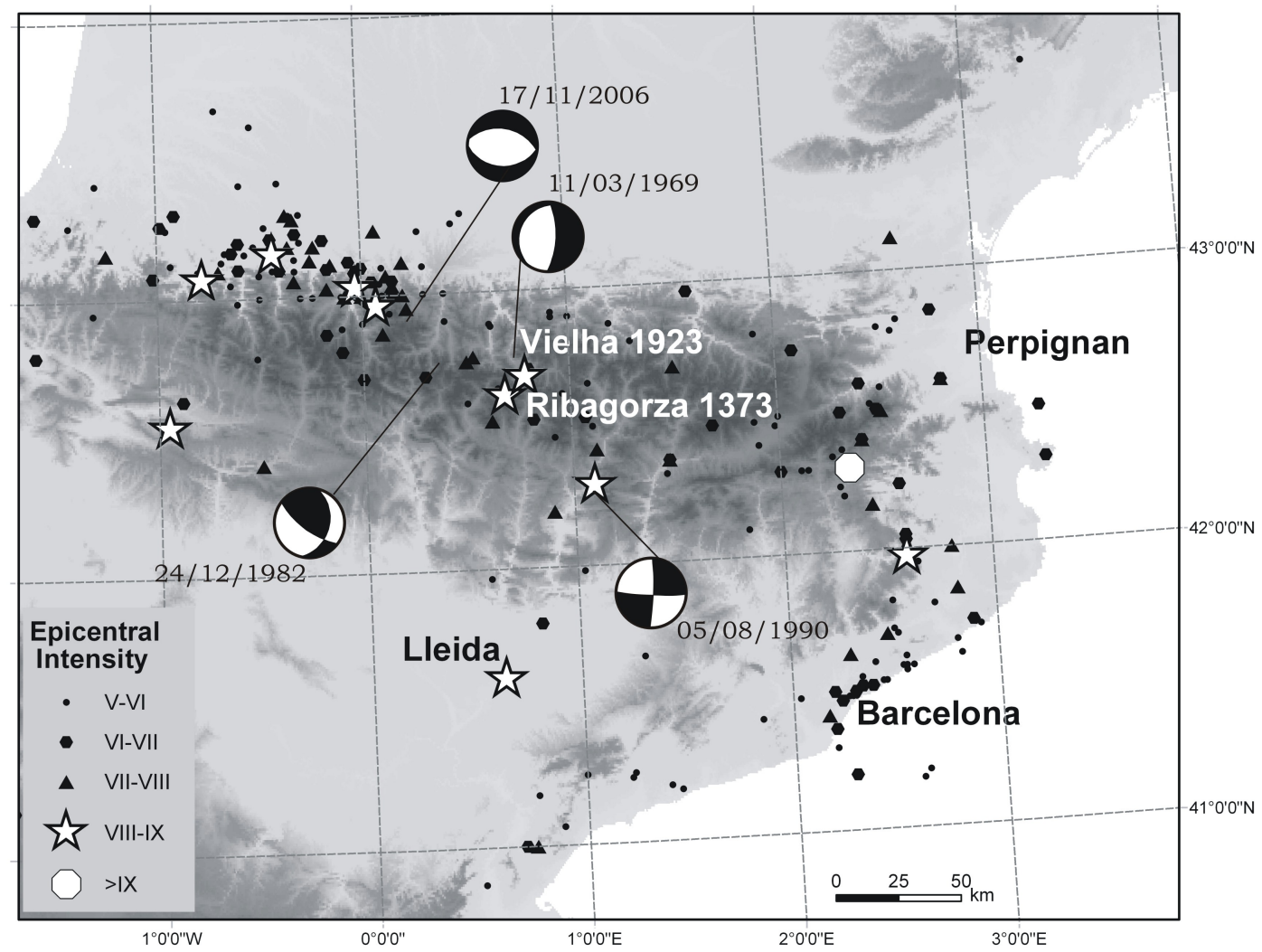

Fig 2 


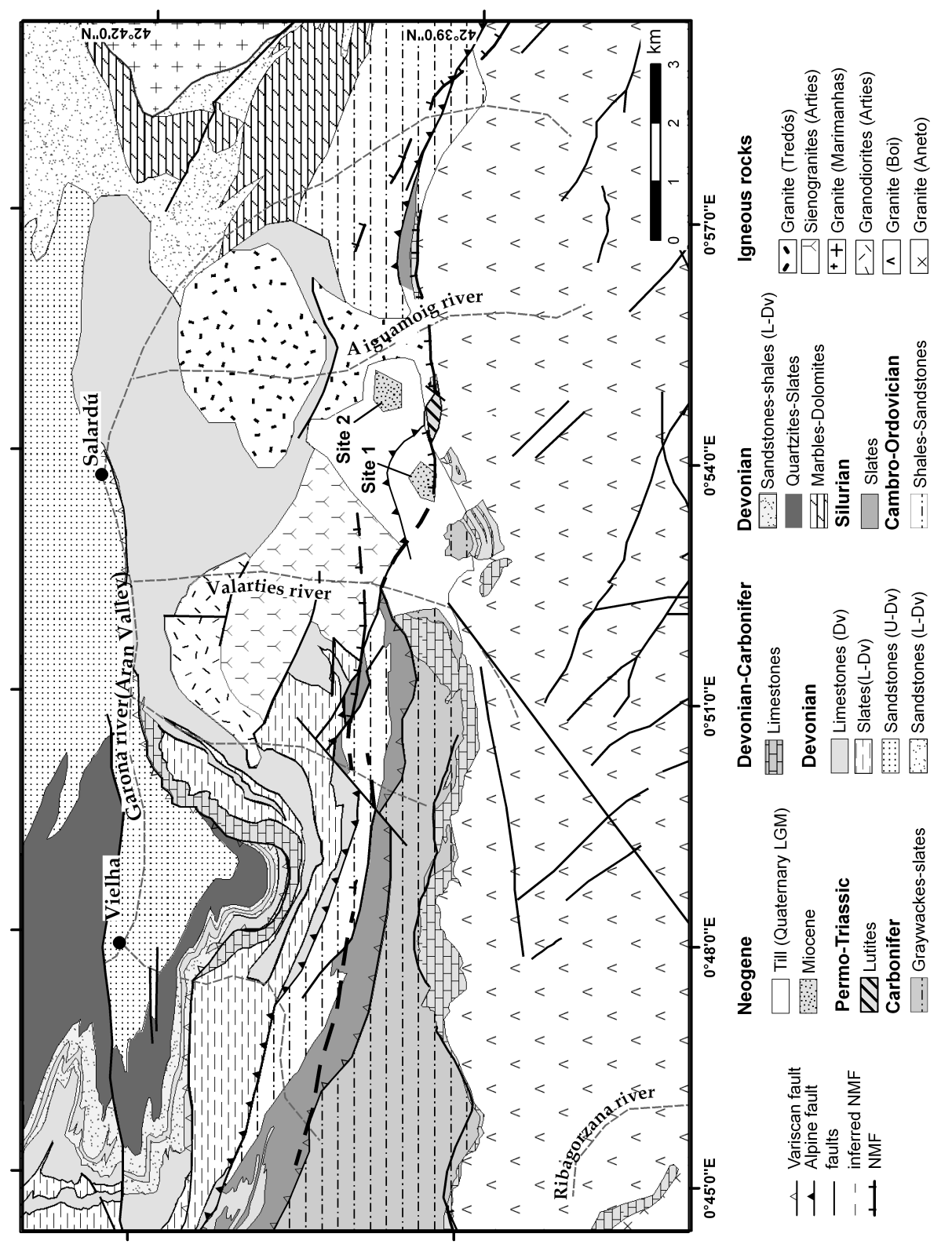

Fig 3 


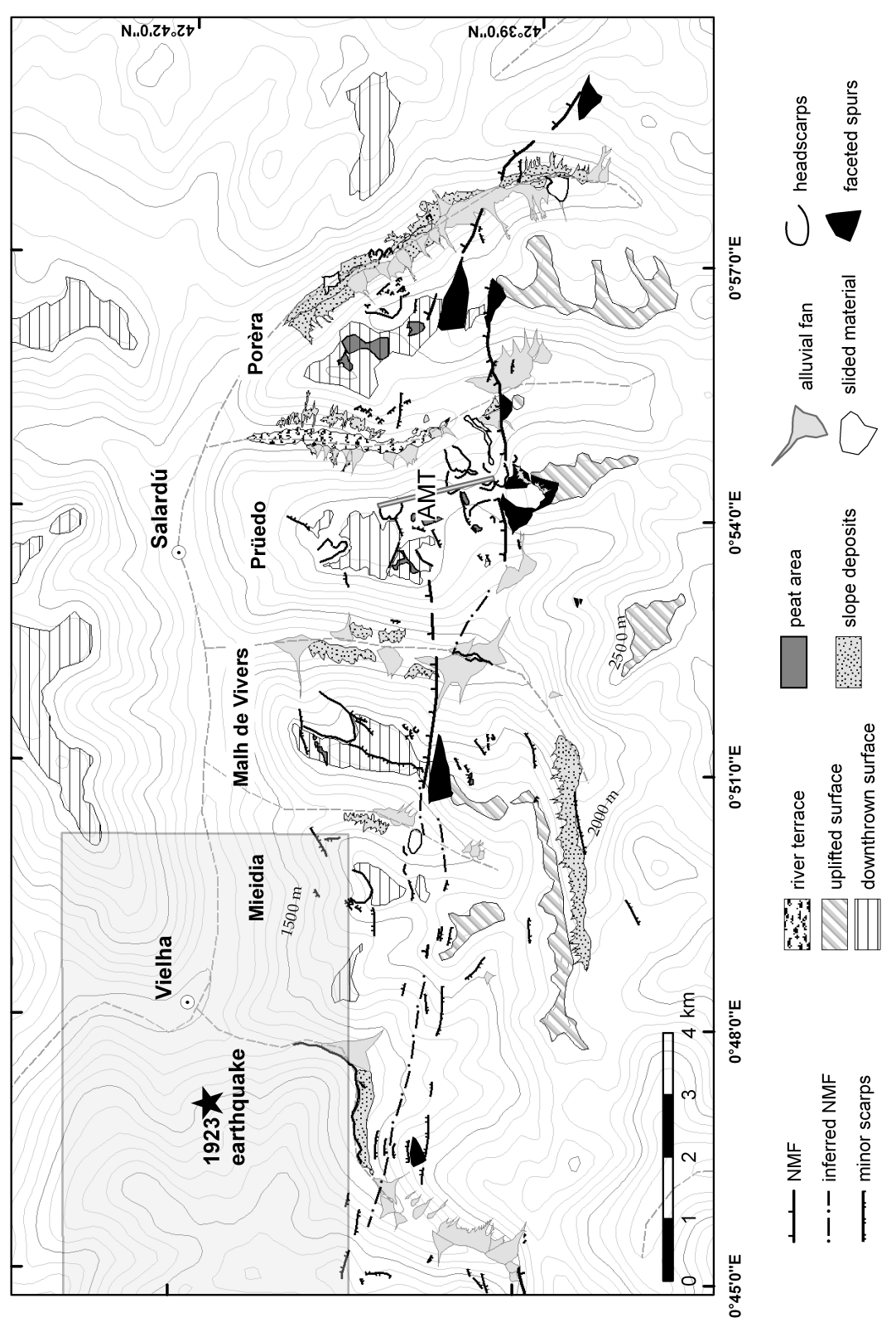

Fig 4 


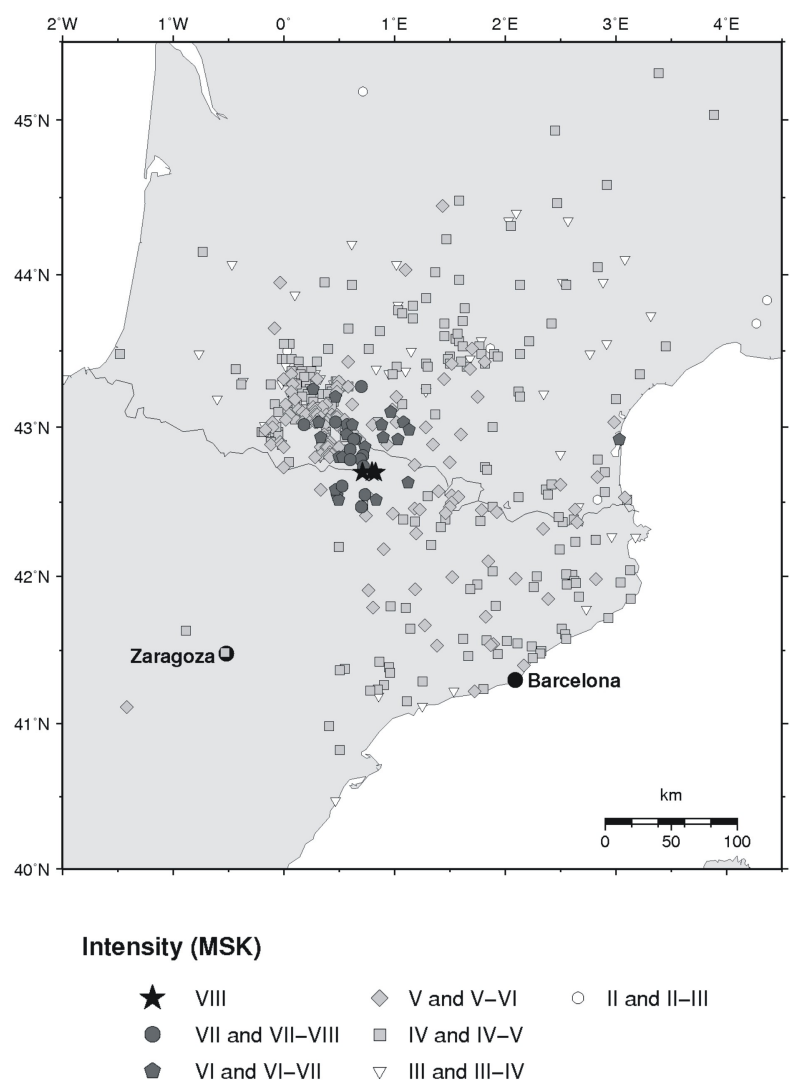

Fig 5

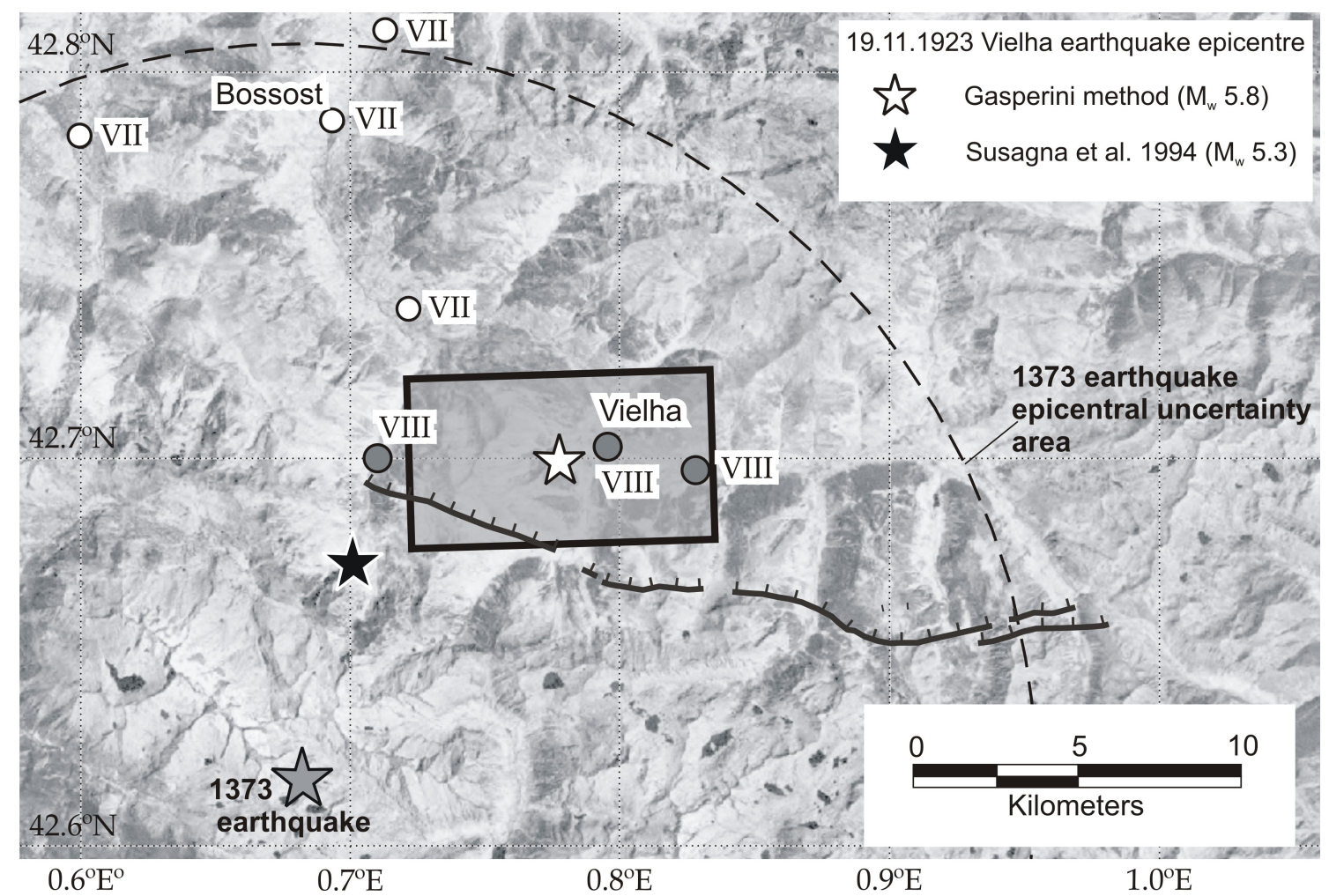

Fig 6 

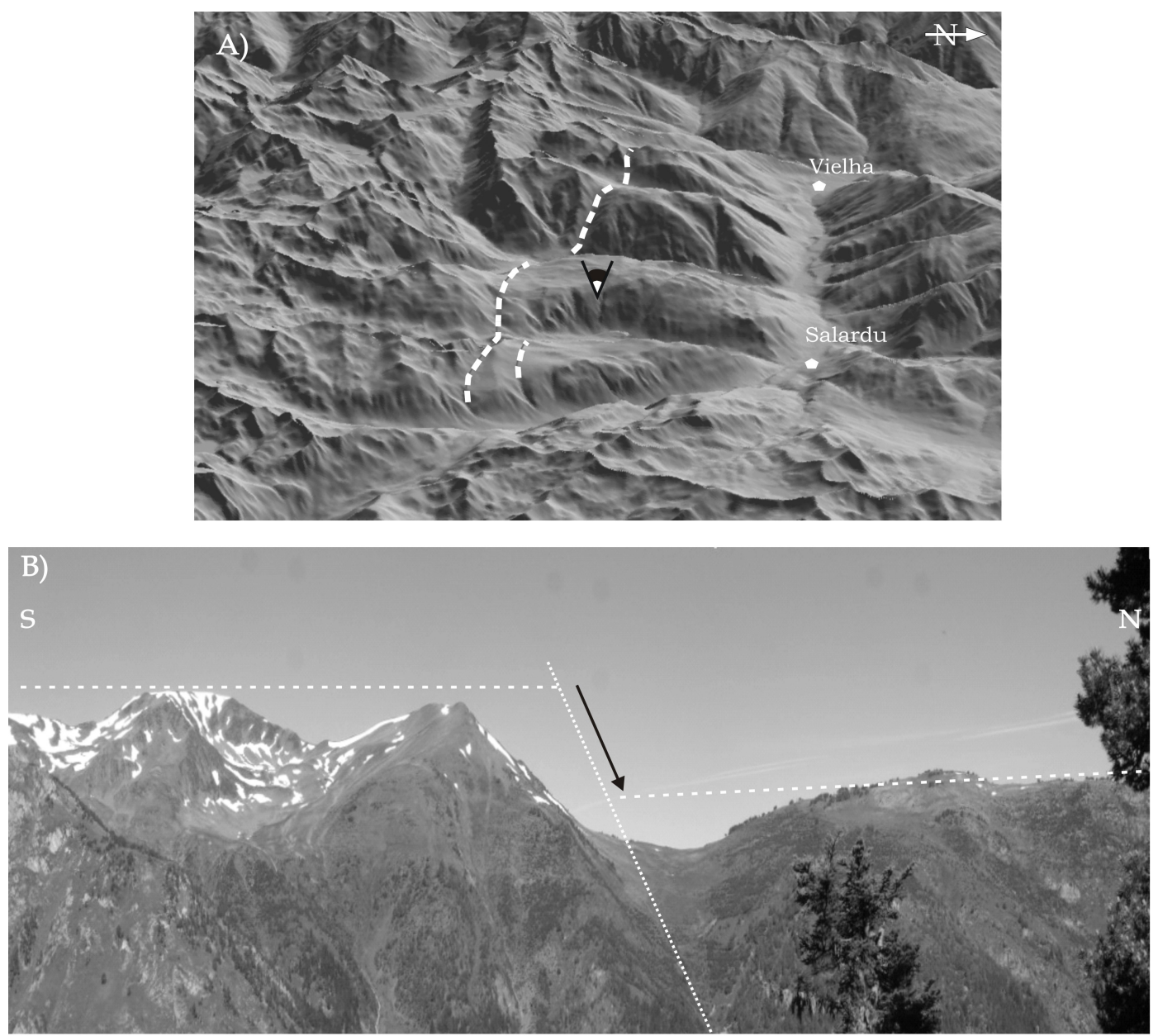

Fig 7 


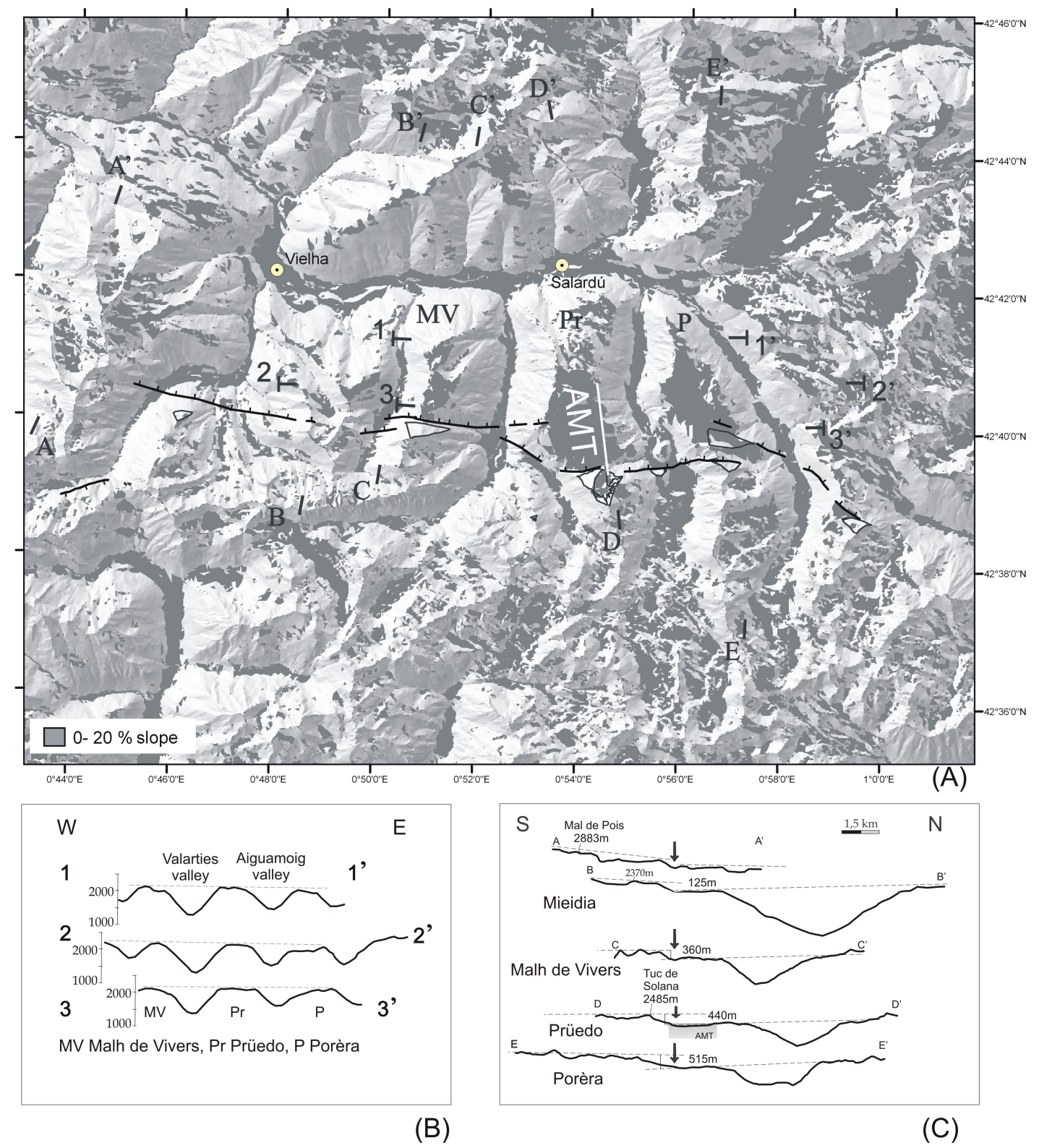

Fig 8 


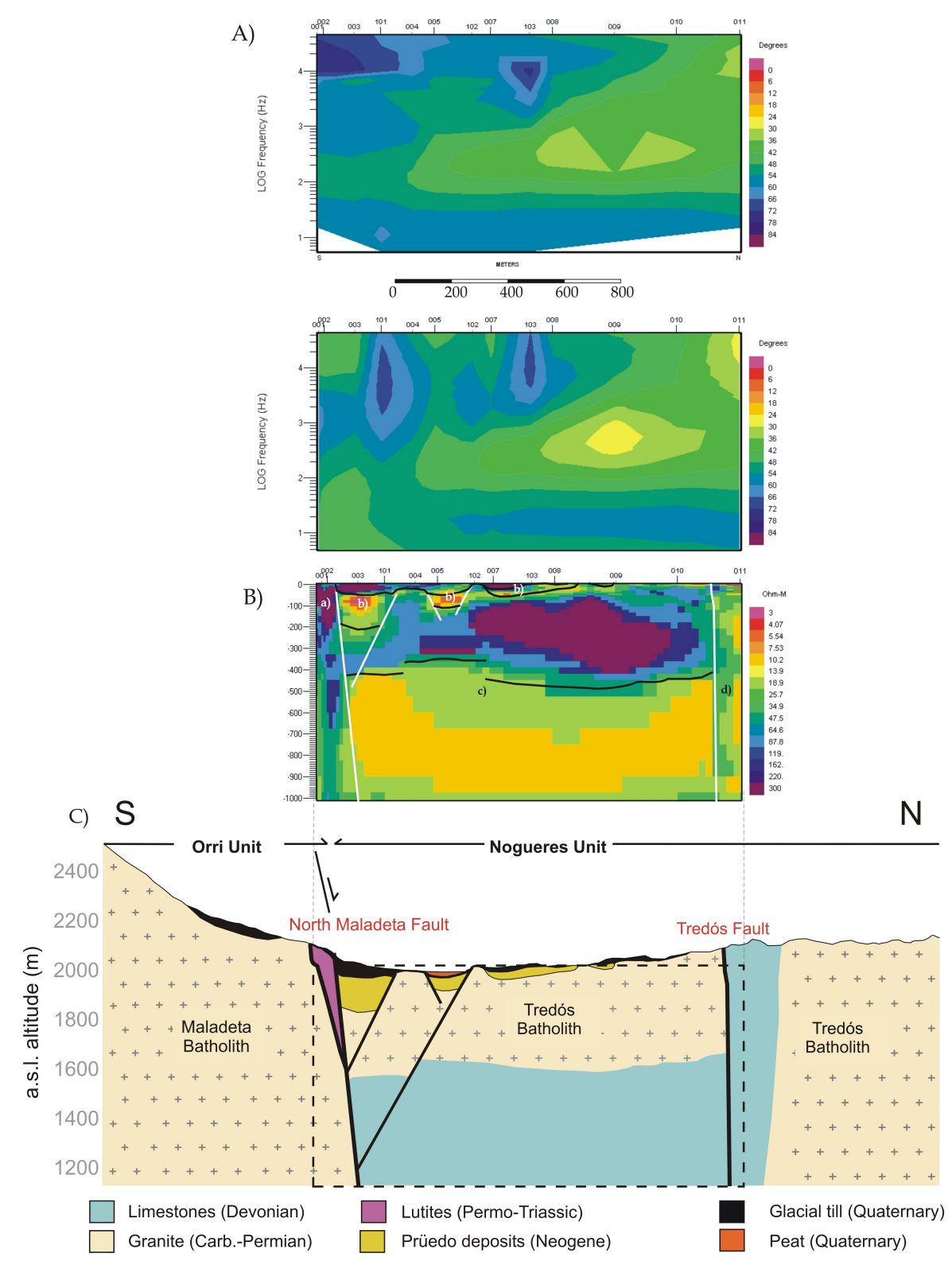

Fig 9 